\title{
Designing optimal scenarios of nutrient loading reduction in a WFD/MSFD perspective by using passive tracers in a biogeochemical-3D model of the English Channel/Bay of Biscay area
}

\author{
Ménesguen Alain ${ }^{1,{ }^{*}}$, Dussauze Morgan ${ }^{2}$, Dumas Franck $^{3}$ \\ 1 Ifremer, Centre de Bretagne, Département DYNECO, CS 10070, 29280 Plouzané, France \\ ${ }^{2}$ Actimar, 36 quai de la Douane, 29200, Brest, France \\ ${ }^{3} \mathrm{SHOM} / \mathrm{DOPS} / \mathrm{HOM} / \mathrm{REC}, 13$ rue du Chatellier, CS 92803, 29228, Brest Cedex 2, France \\ * Corresponding author : Alain Ménesguen, email address : amenesg@ifremer.fr
}

\begin{abstract}
:
In most cases, eutrophication of a coastal zone is a multi-source phenomenon. The questions often raised by authorities about these different sources are: what are their marine area of influence and their respective role in the eutrophication process?

A first answer to these questions is proposed for the bay of Biscay-English Channel French coasts, using a hydrodynamical model alone with a passive tracer for each of the main 45 French watersheds of the domain. The statistical marine receiving area of each river is then defined over a whole decade (2000-2010) by using different percentiles (respectively the 10th, 50th, 90th ones) of the distribution of tracer values in each mesh of the grid: this enables to map the dilution areas of each river plume respectively for low water regime, mean flow rate regime and flood regime. If one can impose: $1 /$ the marine winter concentration not to be exceeded to keep a Good Ecological Status, 2/a proxy for the cost of the unitary abatement of the nutrient concentration in each river, this linear dilution model can be coupled to a global optimisation method, in order to compute the set of concentrations in the 45 rivers which allows to obtain at the lowest price the best Ecological Status everywhere in the maritime domain under consideration. Two global optimisation techniques (linear Simplex method and quadratic Beale's method) have been compared on various marine target areas: the marine WFD water masses considered separately or together, the 3 MSFD French sub-regions of the Channel-Biscay area, or the coastal strip laying between the seashore and the $50 \mathrm{~m}$ isobath. Computations have been made using two successive nitrate and phosphate thresholds at sea, which are associated respectively to the WFD eutrophication High Status and Good Status. This exercise has shown that focusing on a single small marine target area can sometimes prescribe a strong abatement of concentrations in the sole small neighbouring rivers, but that dealing with a large marine target area points always to the biggest tributaries as being the main nutrient sources to be diminished, whereas small tributaries can be neglected. As it contains the whole big river plumes, the MSFD target requires stronger abatement of nitrate in some watersheds than the WFD target, which is limited to a thin, 1 nautical mile wide strip along the coasts. Whereas very few rivers (e.g. the Seine river) require some abatement of their
\end{abstract}


phosphate loadings, almost all the medium and large French rivers would require very strong abatements (between 50 and $80 \%$ ) of their nitrate concentrations.

To verify this quick linear approach restricted to winter nutrients, a full non-linear, coupled biogeochemical-hydrodynamical model has been used to compute the effect of these optimal nutrient reduction scenarios on the most characteristic descriptors of eutrophication: chlorophyll 90th percentile, dinoflagellate maximum and bottom oxygen concentration 10th percentile. The results show that nutrient loading reductions enabling a Good Ecological Status everywhere for winter marine nutrients would still leave some marine areas in a Bad Ecological Status in terms of chlorophyll content.

\section{Highlights}

- Statistical plumes of 45 French rivers have been delineated by tracer dispersion. Optimum nutrient reductions were deduced to restore the marine G.E.S. The French rivers require small efforts on $\mathrm{PO}_{4}$ loadings and drastic ones on $\mathrm{NO}_{3}$. A 3D ecological model confirms partially the efficiency of these optimal scenarios.

Keywords : 3D modelling, Regions of freshwater influence, Nutrient loading reduction, Good ecological status, Simplex method 


\section{Introduction}

In several places (bay of Seine and bay of Somme, Brittany and Vendée), the French coastal waters have received during the last decades important loadings of nutrients (nitrogen, phosphorus...) mainly stemming from watersheds with intensive farming. Every year, this enrichment leads to algal blooms of two kinds:

- "Green tides" mainly composed of Ulva, appearing in very shallow waters in April and lasting to the end of autumn, mainly in bays (Brittany) or lagoons (Arcachon, Languedoc ponds) that offer environmental conditions favourable to their growth, i.e. not turbid and nitrogen-rich, and their accumulation, i.e. semi-enclosed sites or sites with low residual drift seaward (Ménesguen and Piriou, 1995).

- "Coloured waters" made offshore by phytoplankton blooms of various species (diatoms, dinoflagellates, prymnesiophytes), some of which may be toxic (Beliaeff et al., 2001).

The European Water Framework Directive (WFD 2000/60/EC) establishes a framework for Community action and sets targets for preservation or restoration of the state of coastal and estuarine waters. The main objective was to achieve by 2015 a good ecological and chemical condition in different environments across the European territory. The Marine Strategy Framework Directive (MSFD 2008/56/EC) reaffirms the same goals, but on larger marine areas and aims to a general Good Ecological Status in 2020. In addition, the OSPAR Commission (http://www.ospar.org) resulting from the cooperation between the European Community and the governments of fifteen islands and coastal countries of Western Europe is also developing an evaluation strategy in monitoring five major themes, including eutrophication, in order to protect the marine environment of the Northeast Atlantic. The Common Procedure for assessing the level of eutrophication adopted by the OSPAR commission is based on ten parameters, divided into four categories (level of nutrient enrichment, direct enrichment effects, indirect effects of enrichment and potential additional effects, as the presence of toxins in shellfish). The evaluation is based on the achievement or not of the EcoQO (Ecological Quality Objectives) and can be summarized by assigning each area in one of the three eutrophication categories: "non-problem area", "potential problem area" and "problem area". These different European institutions ask each country for a regular assessment of the status of its coastal waters, and for scenarios of reduction of terrestrial inputs of nutrients able to bring back the Good Ecological Status in the eutrophicated areas.

Going back to river loadings that were common a century ago is not feasible. Nevertheless, the reduction of nitrate load (and/or phosphate) beyond a certain threshold may have a significant impact on algal 
blooms. The difficulty in determining this level of reduction lies in the non-linear relationship between the level of nutrient enrichment and its harmful consequences, the so-called direct enrichment effects (e.g. planktonic biomass) or indirect effects of enrichment (hypoxia of bottom waters). This study therefore starts reasoning purely on winter marine nutrients by using only the hydrodynamic MARS3D model to map the marine "receiving basins" of the major French watersheds flowing into the English Channel and the Bay of Biscay. The respective responsibilities of each of these watersheds will then be used to compute a globally optimal scenario of selective reduction of nitrate and phosphate river concentrations, in order to reach a Good Ecological Status for winter nutrients almost everywhere and with the best efficiency:cost ratio. This will be done in the same spirit as Los et al. (2014) for the total OSPAR zone, but will compare the Linear Programming method (Simplex method) with a Quadratic Programming technique (Beale's method) to a set of various marine targets defined by the European Water Framework Directive and Marine Strategy Framework Directive. Then, the paper ends with a global verification of the efficiency of this nutrient reduction on the direct and indirect harmful effects of eutrophication. This verification uses the fully coupled hydrodynamic/biogeochemical ECO-MARS3D model (Ménesguen et al., in revision), which simulates 17 state variables, describing the nitrogen, phosphorus and silicon cycles and the dissolved oxygen in the pelagic ecosystem, coupled to bulk detrital benthic compartments, and contains three phytoplanktonic groups (diatoms, dinoflagellates and nanoflagellates) along with two zooplanktonic components (microzooplankton and mesozooplankton).

\section{Material and methods}

\subsection{Model grids}

This modelling study of the French Atlantic shelf used a so-called "extended MANGA" grid, which covers the area $41^{\circ} \mathrm{N}$ to $55^{\circ} \mathrm{N}, 18^{\circ} \mathrm{W}$ to $9^{\circ} 30^{\prime} \mathrm{E}$ (Fig. 1) with 514 columns $\mathrm{x} 390$ rows of $4 \mathrm{x} 4 \mathrm{~km}$ meshes, with 30 sigma levels on the vertical. This grid encompasses the Bay of Biscay, the Irish Sea, the English Channel and the southern part of the North Sea, up to the Rhine estuary, with a north-east part fully located on the continental shelf ( depths $\leq 200 \mathrm{~m}$ ), and a south-western part located above the abyssal plain (depths $\geq 4000 \mathrm{~m}$ ). This grid has the advantage of simulating properly ocean currents and their interaction with the continental slope, but generates computing times and storage volumes which are too large to be applied to simulations of biogeochemical model ECO-MARS3D results. It has been mainly used to compute the dispersion of conservative tracers from main rivers, and to map the corresponding marine "receiving basins". For a refined mapping of the marine "receiving 
basins" of small watersheds (e.g. Vire, Elorn, Charente ...), three local zooms with a 1x1 km mesh have been implemented and forced at their boundaries by the results of the "extended MANGA" grid: the "Eastern Channel" grid (343 columns x 229 lines x 10 layers, green lines on Fig. 1), the "Brittany" grid (299 columns x 248 lines x 15 layers, red lines on Fig. 1) and the "Vendée-Landes" grid (183 columns x 331 lines x 30 layers, blue lines on Fig. 1).

For biogeochemical simulations, a smaller grid was used: the so-called "restricted MANGA" grid covers the area $43^{\circ} 12^{\prime} \mathrm{N}$ to $52^{\circ} 45^{\prime} \mathrm{N}, 8^{\circ} 05^{\prime} \mathrm{W}$ to $5^{\circ} \mathrm{E}$ (see black rectangle on Fig. 1), also at $4 \mathrm{~km}$ resolution (244 columns x 265 lines x 30 layers). This "restricted MANGA" is forced at its ocean boundaries by the results of a biogeochemical mean year obtained by a first run of this ECO-MARS3D model on the "extended MANGA" grid.

\subsection{Hydrodynamical model}

The basic tool of this study is a 3D hydrodynamical model, the so-called MARS3D, i.e. "Model for Applications at Regional Scale" (Lazure and Dumas, 2008). This model dedicated to the simulation of shelf seas hydrodynamics is based on Blumberg and Mellor (1987) approach of Navier-Stokes primitive equations with hydrostatic approximation. It calculates the currents, the temperature, the salinity and the dispersion of dissolved elements, using a barotropic-baroclinic splitting mode technique on a $\mathrm{C}$ type Arakawa discretisation. An ADI (Alternating Direction Implicit) scheme is used to solve the barotropic mode. MARS3D uses predictioncorrection technique in order to have the better time step. Vertical eddy viscosity and diffusivity are calculated by the resolution of the turbulent kinetic energy equation and the use of an algebraic formula for the mixing length. Heat and movement transfer at the ocean-surface interface is calculated using computed fields of meteorological variables from Meteo-France ARPEGE model with a $30 \mathrm{~km}$ and $6 \mathrm{~h}$ space-time resolution: air temperature, cloud cover, relative humidity, wind and atmospheric pressure. The boundary condition for free surface elevation comes from a larger MARS2D model, which covers the north-west Atlantic ocean. The boundaries of this large barotropic model are forced by tidal harmonic components provided by the FES2004 atlas (Lyard et al., 2006).

The model receives freshwater inflows from 18 non-French rivers and 45 French watersheds (or catchment groupings), which are listed in Table I and located on Fig. 2. For French rivers, flow measurements are taken from the French hydrologic database (http://www.hydro.eaufrance.fr/) and have been linearly timeinterpolated and space-extrapolated (by the ratio watershed total area : watershed area upstream from the gauge point) from the most downstream gauge station to assess flow values at the marine outfalls; for non-French rivers, 
flow rates were taken in the CEFAS database build for the ICG-EMO OSPAR working group. The salinity measurements used for validating the dilution of freshwater into the coastal zone come from the Ifremer ROCH, REPHY, SRN monitoring data bases and from the two automatic MAREL buoys moored in the bay of Brest and the bay of Vilaine.

\subsection{Construction of statistical "receiving basins"}

Unlike continental watersheds, which result from the fixed position of slopes and crest lines in a static landscape, their marine counterparts, that we will name the "receiving basins", are not static and not definable by a unique border line because they are based on the time-varying extension of the river dilution plumes. We will then use a statistical definition of the "receiving basins", based on two parameters: the duration of the period used for establishing the statistics, and the percentile retained in the statistical distribution obtained. In this study, we have chosen a 11 year period (2000-2010) and 3 levels of plume extension: the $50^{\text {th }}$ percentile (defining the median "receiving basin"), the $10^{\text {th }}$ percentile (associated to the summer low water regimes) and the $90^{\text {th }}$ percentile (associated to the winter flood regimes).

To map the dilution plume of a given river, its water is marked by a specific tracer injected continuously at a concentration equal to 1 , whereas the mass of seawater in the model has an initial concentration equal to 0 everywhere for that tracer. A spin-up period is necessary to reach a quasi-periodic situation: given the size of the MANGA grids, a 2 year spin-up period (1998-1999) has been considered as sufficient to obtain well established tracer plumes. The decade actually simulated (2000-2010) represents the inter-annual variability of flows (wet years, medium and dry, see Table II), and provides in each cell of each layer of the model a time series of $11 * 365$ daily concentrations of the tracer. For a given mesh of the surface layer, this time series can be ordered by ascending values to build the cumulative distribution function over the 11 year period (Fig. 3). Mapping the 50, 10 or 90 percentiles of the tracer obtained independently in each mesh provides a rather smooth delineation of the 3 extensions of the "receiving basin". In the case of Astan station shown on Fig. 3, the $90^{\text {th }}$ percentile in this cell is equal to 0.0119 , the $50^{\text {th }}$ percentile to 0.0053 and the $10^{\text {th }}$ percentile to 0.0031 . A "receiving basin" can be precisely mapped by drawing several decadal statistical dilution contours (e.g. 1:25, $1: 50,1: 100,1: 500,1: 1000)$, but in this paper we used only the 1:100 decadal statistical dilution contour in order to be able to superimpose several "receiving basins" on the same map.

\subsection{Optimisation techniques}


Since the 2D surface maps of marine "receiving basins" provide dilution of a conservative dissolved constituent brought by their corresponding watersheds, we can reconstruct the geographic distributions (under a stable median, or low water, or flood regime) of this constituent in the entire marine area of the model from a simple linear combination of the contents of the various rivers and ocean water. This technique is especially appropriate for dissolved inorganic nitrogen in winter, but can also be applied to winter dissolved phosphate if one considers that the suspended particles are saturated with adsorbed phosphate and therefore don't collect dissolved phosphate in the dilution plume of the rivers anymore .

If we can set a threshold not to be exceeded by the marine concentration of the dissolved conservative substance in order to ensure a locally Good Ecological Status for this constituent, we can try to get the optimal set of reductions of this substance in the rivers, which ensures the Good Ecological Status at sea in the maximum of marine meshes and at the lowest price. Two optimization techniques have been compared in this study: one is of order 1 (Dantzig's linear Simplex), the other of order 2 (Beale's quadratic optimisation). For both methods, the definition of the constraints and the cost function to be minimized uses the following common ingredients:

$\mathrm{nm}$ : the number of marine meshes taken into account

$\mathrm{w}_{\mathrm{i}}$ : the weight of mesh $\mathrm{i}$ in the cost function

$\mathrm{y}_{\text {ocean }}$ : the natural basic oceanic concentration of the substance

$\mathrm{y}_{\text {thr: }}$ : the threshold value not to be exceeded in marine waters in order to stay in Good Ecological Status nr: the number of rivers to be treated

$\mathrm{x}_{\mathrm{j}}$ : the concentration of the substance in river $\mathrm{j}$ currently used in the optimizing computation

$\mathrm{x}_{\mathrm{j} \_ \text {present }}$ : the present concentration of the substance in river $\mathrm{j}$

$\mathrm{x}_{\text {pristine: }}$ the pristine concentration of the substance in all the rivers

$c_{j}$ : the cost of a unitary lowering of the substance concentration in the river $j$

$d_{i j}$ : the fraction of the river $j$ concentration which is still present in mesh $i$

$y_{i}=$ the actual concentration of the substance in mesh $i$

$$
y_{i}=\left(1-\sum_{j=1}^{n r} d_{i j}\right) \cdot y_{o c e a n}+\sum_{j=1}^{n r} d_{i j} \cdot x_{j}
$$


Both methods must fulfil the following $\mathrm{nr}$ constraints on river concentrations:

$$
\forall \mathrm{j} \in[1, \mathrm{nr}]: \mathrm{x}_{\text {pristine }} \leq \mathrm{x}_{\mathrm{j}} \leq \mathrm{x}_{\mathrm{j}_{-} \text {present }}
$$

In the Simplex method, the cost function to be minimized (FS) is the total cost of river concentration drops:

$$
F S=\sum_{j=1}^{n r} c_{j} \cdot\left(x_{j_{-} \text {present }}-x_{j}\right)
$$

while respecting the $\mathrm{nm}$ additional constraints on marine concentrations: $\forall \mathrm{i} \in[1, \mathrm{~nm}]: \mathrm{y}_{\text {ocean }} \leq \mathrm{y}_{\mathrm{i}} \leq \mathrm{y}_{\mathrm{thr}}$

The meshes in the vicinity of estuaries in which the substance concentration could never go below the marine threshold, even in the pristine situation, would obviously generate unsolvable equations in this constraints system; they must then be removed from the set of marine meshes taken into account, prior to any computation. The Simplex method will then ensure that the constraints will be respected in each of all the remaining "feasible" meshes. In the Beale's quadratic method, these marine constraints are weakened, so they are considered as penalties in the cost function rather than constraints that must be strictly fulfilled. The Beale's cost function FB then becomes:

$$
\mathrm{FB}=\lambda \cdot \sum_{\mathrm{j}=1}^{\mathrm{nr}} \mathrm{c}_{\mathrm{j}} \cdot\left(\mathrm{x}_{\mathrm{j}_{-} \text {present }}-\mathrm{x}_{\mathrm{j}}\right)+\sum_{\mathrm{i}=1}^{\mathrm{nm}} \mathrm{w}_{\mathrm{i}} \cdot\left[\operatorname{Sup}\left(\mathrm{y}_{\mathrm{i}}-\mathrm{y}_{\mathrm{thr}}, 0\right)\right]^{2}
$$

The penalty for non-respecting the threshold concentration is computed only on meshes which exhibit a current concentration above the threshold, and the scaling factor $\lambda$ factor is used to give more or less weight to the river concentration drops relatively to the cost of letting some marine meshes above the fixed threshold concentration. The fact that a mesh may go out of the cost function as soon as the descent algorithm has lowered the marine concentration in that mesh under the threshold does alter the cost function during the optimisation process, whereas it remains unchanged during the whole Simplex procedure. This difficulty has been empirically solved by iterating the whole Beale's method until the cost function does not change anymore.

For the cost of a unitary lowering of a nutrient concentration in a river, since no homogeneous and generalized financial assessment is available, we have chosen the watershed area as a proxy; it is similar to the mean flow rate taken by Los et al. (2014). 


\subsection{Biogeochemical model}

The basic biogeochemical model ECO-MARS3D (Fig. 4) has been extensively described and validated by Ménesguen et al. (in revision). It contains 17 state variables, describing the nitrogen, phosphorus and silicon cycles and the dissolved oxygen in the pelagic ecosystem. Three limiting dissolved inorganic nutrients are considered: nitrogen, with nitrate and ammonium separately, phosphorus, and silicon. Phytoplankton is divided into 3 groups: diatoms, dinoflagellates and nanoflagellates, with concentrations expressed in nitrogen currency. Chlorophyll is deduced from the nitrogenous state variables of the model by an empirical Chl:N ratio, computed as a Smith-like formula (Smith, 1936) depending on the local extinction coefficient. There are two zooplanktonic components, expressed in nitrogen units: the microzooplankton, which eats diatoms, dinoflagellates, nanoflagellates and detrital particulate matter, and the mesozooplankton, which eats diatoms, dinoflagellates and microzooplankton. So, in this model, diatoms do sink, whereas nanoflagellates and dinoflagellates do not, as they are considered as able to maintain at any depth in calm water, thanks to motility. Three particulate detrital variables, detrital N, detrital P, and detrital Si close the biogeochemical cycles, and settle in the water column; in the bottom layer, each settling fraction is partially transferred to a fixed state variable, which can give back to the water layer some particulate material through erosion by currents, and some dissolved equivalent after remineralisation. 


\section{Results}

\subsection{Validation of the dilution model}

As it can be seen in Table II for the 3 main French rivers, over the period 2000-2010, the wettest year was 2001, the driest one was 2005 and the year closest to the year average was 2007 .

As the statistical "receiving basins" will be based on the dilution of river tracers, a first step is to validate the dilution of freshwater inflow in the marine domain by comparing measured and simulated salinities in 7 stations located along the French coast (Fig. 2). The salinity simulated by the 3 refined grids compares favourably to the salinity measurements (Fig. 5_S) and reproduces the winter drops of salinity caused by the river flow periods. The associated Taylor and target diagrams (Fig. 5) point out a correlation around 0.7 (but up to 0.85 at Portzic station in the bay of Brest) along with a standardised bias lower than $50 \%$ of the standard deviation of the measurements, i.e. $0.6 \mathrm{psu}$. The normalized standard deviation of the simulated time-series remains between 0.5 and 1.1 , which means that the variability of the salinity is correctly reproduced. From that coastal validation, we conclude that the MARS3D model is well-suited for mapping the coastal dilution plumes of the main French rivers.

\subsection{Maps of the statistical French "receiving basins"}

The 2000-2010 simulations made on the wide "extended MANGA" grid and the 3 local, refined grids ("Eastern Channel", "Brittany" and "Vendée-Landes" grids) have provided separate maps of the main French rivers (Fig. 6) and the small ones (Fig. 7). The Seine river shows a "receiving basin" well confined to the southern border of the eastern Channel and the southern bay of the North Sea, which corroborates the so-called "fleuve côtier" deduced from measured salinity transects by Brylinski et al. (1991) and the simulated plume of Seine river obtained by Lacroix et al. (2004). The Loire plume clearly enters the English Channel especially after flooding periods, as studied by Kelly-Gerreyn et al. (2006). The Gironde "receiving basin" stays mainly in the middle of the Bay of Biscay, whereas the Adour "receiving basin" can spread along the Basque Country (Spain) during flood periods, as analysed by Ferrer et al. (2009). The smaller French rivers produce only limited plumes, and their statistical "receiving basins" remain confined along the coast near their estuary. Whereas the main rivers do have a long range influence on coastal sea enrichment and can favour blooms off-shore, the small rivers can only cause local perturbations, not far from the coastline. The 45 rivers under study provide empirical powerlaws between the watershed and its "receiving basin" areas under various flow regimes (Fig. 8). 


\subsection{Optimal scenarios of reduction of nitrate and phosphate French loadings}

The study has been done separately on two dissolved substances: nitrate and phosphate. As the statistical "receiving basins" approach considers the river flow rates as fixed (high, median or low) values, the nutrient concentrations must also be considered as constant. The present concentrations of nutrients in the 45 French rivers have been fixed to their mean value over the 2000-2010 period (Table I), the pristine concentrations in all these rivers has been considered as being $10 \mu \mathrm{mol} / \mathrm{L}$ for nitrate and $3 \mu \mathrm{mol} / \mathrm{L}$ for phosphate. These pristine values are compatible with those gathered by Meybeck (1989), who found nitrate concentrations were lower than $14 \mu \mathrm{mol} / \mathrm{L}$ and phosphate concentrations lower than $0.8 \mu \mathrm{mol} / \mathrm{L}$, as well as those simulated by Desmit et al. (2018) for 174 watersheds of the North-East Atlantic under pristine conditions: nitrate concentrations were lower than $32 \mu \mathrm{mol} / \mathrm{L}$ and phosphate concentrations lower than $1 \mu \mathrm{mol} / \mathrm{L}$ Based on the hypothesis that the oceanic western boundary is far enough from the rivers under concern to have been unchangedby their recent increased loadings, the baseline oceanic concentrations in winter have been set to 5 $\mu \mathrm{mol} / \mathrm{L}$ for nitrate and $0.3 \mu \mathrm{mol} / \mathrm{L}$ for phosphate, i.e. the surface values currently observed off the continental slope at the middle latitude of the area under concern (Loyer et al., 2006). A sensitivity study of the FB cost function of the Beale's method to the weight $(\lambda)$ of the river concentration drops has revealed a sigmoid-like dependency (Fig. 9) of the residual area remaining above the quality threshold to the logarithm of $\lambda$. The final value $\lambda=1$ has been chosen as a good compromise.

A very sensitive parameter of the optimisation process is the marine threshold not to be exceeded; as far as dissolved nutrients in seawater are concerned, no legal threshold value does exist. Such European or national thresholds can be found only for some descriptors of some deleterious effects of eutrophication, chlorophyll or dissolved oxygen concentrations. Going back from chlorophyll threshold to nutrient threshold is not easy, and will depend non-linearly on several local features (residence time, turbidity, phytoplanktonic flora, etc...). For the OSPAR zone, the ICG-EMO working group (OSPAR, 2013) has used different nutrient thresholds for France, Belgium, the Netherlands, Denmark and the United Kingdom, based on national recommendations; they varied between 10.8 and $30 \mu \mathrm{mol} / \mathrm{L}$ for Dissolved Inorganic Nitrogen, and 0.68 and $1.2 \mu \mathrm{mol} / \mathrm{L}$ for Dissolved Inorganic Phosphorus. For Atlantic and Channel French water masses, Daniel and Soudant (2010) computed WFD nitrate marine thresholds by inverting the empirical curve linking the Ecological Quality Ratio of chlorophyll to the nitrate concentration at salinity 33 psu that they could deduce from measurements in the plumes of the Seine, Loire and Gironde rivers. For nitrate only, they obtained $16 \mu \mathrm{mol} / \mathrm{L}$ for the threshold 
between High and Good Status, and $29 \mu \mathrm{mol} / \mathrm{L}$ for the threshold between Good and Moderate Status. In this study, we applied successively the optimisation procedure with two sets of thresholds, called respectively the High Status set (nitrate: $15 \mu \mathrm{mol} / \mathrm{L}$, phosphate: $1 \mu \mathrm{mol} / \mathrm{L}$ ) and the Good Status set (nitrate: $30 \mu \mathrm{mol} / \mathrm{L}$, phosphate: $2 \mu \mathrm{mol} / \mathrm{L}$ ). In accordance with the OSPAR ICG-EMO group, but in disagreement with Daniel and Soudant (2010), we compared these threshold values to the raw computed nutrient concentrations, regardless of local salinity.

The level and the distribution among rivers of the optimal reduction of nutrients will depend strongly of the size and location of the marine target area under study. We compared 3 types of targets (Fig. 10): the 73 WFD marine water masses covering the French coast of the English Channel and the Bay of Biscay (one by one, or merged in a single target area), the 3 French MSFD sub-regions and the whole coastal strip of the "restricted MANGA" grid with depths between 0 and 50m.

The Simplex method applied to these various marine targets produces very contrasted results between nitrate and phosphate, whatever the level of exigency in marine thresholds (Fig. 11 upper and medium panels and Table III). For most rivers, the optimal level of nitrate reduction is very high $(>80 \%$ in High Status, $>60 \%$ for Good Status), whereas it remains null for phosphate in most rivers (37 rivers in High Status, 44 river for Good Status). Among the main rivers, only the Seine river still requires a strong phosphate abatement (80\%) in case of High Status. This first conclusion can be explained by the strong reduction of urban phosphate loadings achieved during the 20 last years by banning polyphosphate in washing powders and by precipitating dissolved phosphate in waste water treatment plants, whereas nitrate leaching from intensive agriculture has increased (Billen and Garnier, 2007). Varying the size and location of the marine target clearly selects different rivers for nutrient reduction, but also changes drastically the level of abatement required (Table IV_S). For instance, whatever the nutrient $\left(\mathrm{NO}_{3}\right.$ or $\left.\mathrm{PO}_{4}\right)$ and the optimisation technique, the Celtic Sea MSFD sub-region does not require any abatement in the 45 French rivers, because of its natural low levels of enrichment. Small marine targets as individual WFD water masses will focus on neighbouring rivers: this explains the pseudo-diagonal aspect of Table IV_S, where rows are the water masses and columns the rivers both from north to south. So, looking separately at small marine targets will recommend a strong abatement on neighbouring small rivers, rather than involving the main rivers not far from the target area. For instance, when considered alone, the Saint-Vaast la Hougue water mass, in Normandy, requires the return to nitrate pristine conditions in 3 small rivers (Orne, Douve, Vire) and no abatement in all the other rivers, including the Seine, whereas if that water mass is 
considered along with all the other French water masses, the same High Status can be achieved by no abatement in the Vire, only $32 \%$ in the Douve, but various abatements in a lot of other more distant rivers, including $92 \%$ for the Seine river. Mapping the marine nitrate with a color scale for meshes above the critical nitrate threshold and a gray scale for those below shows clearly the complete cleaning effect of the Simplex optimisation process (Fig. 12 right) compared to the present situation (Fig. 12 middle).

The Beale's method applied to the same marine targets produces results similar to those of the Simplex method, but less stringent and less focused on a subset of rivers (Fig. 11 bottom panel and Table III). The possibility offered to slightly violate the Good Ecological Status (but to pay for that) induces a spreading of reduction effort on almost all the rivers, but at a lower level on each. For instance, for the High Status scenario, the Simplex approach requires 50\% nitrate reduction (or more) in 35 rivers, and no reduction in only 8 rivers, whereas the Beale's approach requires 50\% nitrate reduction (or more) in only 25 rivers, and a lower level in all the other rivers: none of the 45 rivers can still remain without any nitrate reduction.

\subsection{Verification of the efficiency of optimal nutrient reductions on the chlorophyll and oxygen concentrations}

As the most reliable descriptors of eutrophication impact are not the winter nutrient levels, but the spring-summer levels of chlorophyll and bottom dissolved oxygen, the ECO-MARS3D model of the pelagic ecosystem which has been used to simulate the real situation during the 2000-2010 decade and validated against a coastal data base (Ménesguen et al., in revision) has been forced by globally optimal scenarios coming from the previous linear approach, first for 2 years of spin-up (2005-2006) and then for the year 2007 (year with medium flow rates) in order to assess the effects of loading reduction upon some ultimate criteria of marine eutrophication, the $90^{\text {th }}$ percentile of chlorophyll and the $10^{\text {th }}$ percentile of bottom dissolved oxygen.

First of all, the geographical distribution of winter nutrient simulated by the ecological model for the January-February period of the "medium" year 2007 can be compared with the mean stable richness computed by the linear superposition of 45 river plumes previously described. But, as the linear river plume approach has been made only for the French rivers, whereas the ecological model takes into account also the main non-French rivers in that area, the two maps can be compared only along the French coasts. For example, the Figure 12 shows the actual nitrate distributions in the $0-50 \mathrm{~m}$ bathymetric strip. Using a double colour bar, in greys for areas having nutrient concentrations below the High Status nitrate threshold $\left(15 \mu \mathrm{mol} / \mathrm{L} \mathrm{NO}_{3}\right)$ and in colours for areas above it allows a visual appraisial of the actual problem areas in the two approaches: the linear superposition of 45 river 
plumes (Fig. 12 middle) points globally the same areas as the 2007 simulation (Fig. 12 left), but gives them a slightly smaller extent. This is due to the fact that the winter concentrations simulated by the complete ecological model are systematically higher than concentrations computed only from dilution of the mean annual river loadings, because they take into account not only the fresh inputs from rivers, but also local marine fluxes brought by the remineralisation of pelagic and benthic detrital matter. The situation is comparable, but with a more acute difference, for phosphate maps.

Concerning the simulated effects of optimal nutrient reductions on chlorophyll and oxygen, the results are:

- in eutrophicated areas, the chlorophyll $90^{\text {th }}$ percentile (Fig. 13) begins to decrease significantly only in case of "High Status" optimal scenarios of nitrate and phosphate loading reduction, clearly more in the Eastern Channel (off the Seine estuary) than in the Bay of Biscay (off the Loire and Vilaine estuaries). This mirrors the behavior of the main component of the phytoplankton, the diatoms, which are mainly silicon-limited. On the whole maritime area covered by the model, the total area which can be considered as in Bad Status for chlorophyll (i.e. with a chlorophyll $90^{\text {th }}$ percentile above $9 \mu \mathrm{g} / \mathrm{L}$ ) moves from $2480 \mathrm{~km}^{2}$ in the actual situation to $2176 \mathrm{~km}^{2}(-12.5 \%)$ in the nutrient Good Status scenario and to $1808 \mathrm{~km}^{2}(-27 \%)$ in the High Status scenario, when the Beale's algorithm is used. It turns to $1728 \mathrm{~km}^{2}(-30.5 \%)$ in the nutrient Good Status scenario and to $1136 \mathrm{~km}^{2}(-54 \%)$ in the High Status scenario, when the Simplex algorithm is used. The fact that the relative decrease of chlorophyll is always less than the nutrient relative abatement imposed in rivers illustrates clearly the non-linear response of phytoplankton biomass to nutrient concentrations.

- the dinoflagellate annual maximum however (Fig. 14) seems to respond quickly to nitrogen loading decrease, and this is enhanced in case of coupled phosphate loading decrease. Even in case of the nutrient Good Status scenario, the dinoflagellates regress in all the enriched and summer stratified area, i.e. the continental shelf of the bay of Biscay, and the eastern bay of Seine in the English Channel; in case of the more stringent nutrient scenario (High Status scenario), their decrease may exceed $90 \%$.

- the oxygen $10^{\text {th }}$ percentile is nearly insensitive to loading reductions: it may increase by $10 \%$ in case of the nutrient High Status scenario. In the English Channel, the strong tidal regime is able to mix the whole water column in summer, even in the Seine plume, so that no significant bottom oxygen depletion is observed nor simulated even in the current loading situation. In the western part of the domain (bay of Biscay and Western approaches of the English Channel), which is thermally stratified during summer, a moderate bottom oxygen 
depletion is simulated on the continental shelf, especially in the shallow Vilaine bay (east from Men-er-roué station on Fig. 2), which receives the plumes of Vilaine and Loire rivers. The specific trapping capacity of this French Atlantic continental shelf due to its weak horizontal tidal residual circulation, along with its vertical stratification during summer may probably explain the fact that some moderate hypoxia is present as far as the phytoplanktonic biomass grows above the very low pristine level.

\section{Discussion}

The size of river plumes has been studied by several authors. For small mountainous rivers, Warrick and Fong (2004) deduce from satellite images of visible turbid plumes in Morocco and California that the plume areas are linked to watershed areas by a power function with exponent around $0.60-0.63$. Their use of the 3D hydrodynamical model ECOM-3D to simulate the dilution of nine small Californian rivers in a theoretic ocean without tide and wind provides also a power-law relationship between the watershed area and the marine area inside a given isohaline; for the isohaline 0.5 psu below the oceanic boundary salinity, the power is 0.70 . Adding results from large rivers (up to the Amazon) studied in the world by various authors confirm their power law with an exponent around 0.68. On the contrary, Nezlin et al. (2005), analyzing the size of 110 Californian river plumes on SeaWiFS satellite images taken after rainy episodes, found that the exponent of the power law linking the plume area to the accumulated stormwater (i.e. a flow rate proxy) was always greater than 1 , going from 1.16 to 1.68. Our results are clearly in favour of this second kind of relationship, with a power law exponent of about 1.3 , and a fit of this power law to data increasing from low $\left(10^{\text {th }}\right.$ percentile $)$ to high $\left(90^{\text {th }}\right.$ percentile $)$ flow rates situations. This can be explained first by the fact that our results are based on realistic 3D modelling, using varying tide and wind effect on a 10-year basis, particularly the strong vertical mixing created by spring tides, which can rapidly totally mix small freshwater inflow into the marine water column, but not high freshwater inflows, which are therefore able to maintain a strong haline stratification far from their mouth and spread wider than small ones. A second explanation to the disagreement with Warrick and Fong's results is that, in our study, the plume is defined for a dissolved tracer as the region inside the decadal statistical 1:100 dilution contour, that is to say the 34.65 psu isohaline in a sea with uniform 35 psu salinity. This area is obviously broader than the turbid plume, which is delineated according to a particulate, settling substance. 
The example of a WFD small water mass taken alone or as part of a global national WFD target has shown in an exacerbated way how the definition of the marine target is a very crucial step in the elaboration of a river load reduction strategy. In that perspective, this study shows that dealing with extended areas such as the MSFD sub-regions or a wide bathymetric strip may lead to a strategy of terrestrial nutrient loading reduction more focused on the big rivers and less demanding for the small ones than dealing only with the narrow, one nautical mile wide, strip of WFD water masses, because of the important spreading of the big river plumes on the continental shelf. Note however that our model, with its $4 \times 4 \mathrm{~km}$ mesh, is not focused on the first nautical mile offshore of the baseline (i.e. the WFD target), but deals with the whole continental shelf at a regional scale (i.e. more in the scope of the MSFD). In the same way, it is focused on the effect of nutrients on phytoplankton only, not on benthic macroalgae, a fact which explains the main role of big rivers. Looking also to small estuaries and to beaches covered by green algae mass blooms, such as Ulva "green tides" in Brittany, would have obviously called for more drastic reductions of nitrogen loadings in small rivers than presented here (Perrot et al., 2014).

Apart from the size of the marine target, an important determinant of the final result is the way the current status of the target is put into the constraints. Los et al. (2014) have chosen to depict a target area by only one constraint dealing with the mean of nutrient concentration in that target; this has the advantage of diminishing the risk of having "unfeasible" targets, by averaging highly enriched meshes near the estuary with more oceanic meshes offshore. But then the question arises: is there a natural, non-arbitrary size of marine targets, which will simplify the computation process without distorting the results? Increasing the size of targets will lower the mean marine concentration, then the required drops in river concentrations, until a size large enough to ensure that the mean concentration in the present situation is lower than the quality threshold, and that no eutrophication problem does exist! This study is in favour of depicting any marine target by as many constraints as there are grid meshes in that target, because this approach is insensitive to the target size. However, in case of the Simplex method, this approach remains dependant on the mesh size, generates possible "unfeasible" constraints (but the corresponding meshes are then excluded from the system to be solved) and may produce excessively stringent nutrient reductions in rivers, due to the "feasible" meshes which are the closest to the river mouth. This drawback can be avoided by techniques, as the Beale's method, which consider marine threshold as guidelines the system can go beyond but with a heavy cost, rather than strict walls the system cannot cross. Such methods can bring a fruitful trade-off between efficiency and feasibility, more acceptable than the brutal optimum computed by the Simplex method. 
From an operational point of view, the choice of a strategy for loading reduction appears indeed to be crucial. If nearly the same quality objective can be reached by two opposite strategies, the first putting a very heavy effort on the sole main watersheds and the second spreading a weaker effort on all the watersheds, stakeholders will opt for the second one, because it is socially easier to impose a medium or weak constraint to all the watersheds rather than to require a very hard effort from some of them while the others remain unaffected. Up to now, as the guiding principle has been more political (equity) than field efficiency, the simplest solution (i.e. apply the same percentage of load reduction to all the watersheds, regardless of their size) has been adopted, even for huge sets of watersheds causing severe and extended hypoxia episodes in marine waters, such as the Mississippi in the Gulf of Mexico (National Research Council, 2009) or the tributaries to the Chesapeake Bay (Linker et al., 2013). In this last case however, a coupled watershed-bay model has been used to assess the effectiveness of each watershed loading in the marine eutrophication symptoms, in order to linearly reduce the basic abatement ratio when the effectiveness decreases. The automatic search of an optimum allocation of reduction effort is a recent topic, because it needs operating a pre-existing model of the marine ecosystem and/or the watersheds. It can be used on line inside the iterating optimisation process: for instance, Rabotyagov et al. (2010) use a genetic algorithm and a Pareto's rule to find a space-distributed optimum allocation of loading reductions. But it can also be used only before the optimisation process, to generate synthetic information off-line (advective fluxes, remote dependency to the inputs...). As in Los et al. (2014), this study uses the 3D model offline to compute a static map of the spatial influence of the different sources, which is used afterwards in a separate and quick optimisation process to generate a static optimal allocation of reduction effort. A future improvement of this off-line approach should be the introduction of a time dimension in the optimisation process, as Gren (2009) did. He used a control theory approach to compute an optimal time-course allocation of nitrogen and phosphorus reduction in the Baltic Sea for the future 70 years.

\section{Conclusion}

This study has been done to infuse some optimality search in the hard question of allocating the national effort of nutrient loading reduction between watersheds of various sizes and present nutrient richness. The aim of an optimal reduction scenario is to ensure at the least cost a Good Ecological Status (as defined in the European MSFD) or a High or Good Status (as defined in the European WFD) in some coastal marine waters. 
The constraint to use only linear or quadratic cost functions to keep the problem treatable by efficient optimisation techniques (Simplex or Beale's methods) has limited the study to the conservative nutrients in winter (nitrate and phosphate), and the method has not been applied to chlorophyll, due to the complex non-linear, timeand space-dependent relationships between nutrients and chlorophyll. However, the optimal sets of nitrate and phosphate reductions in 45 French rivers obtained on winter nutrients have been tested afterwards in a 3D biogeochemical model, and revealed to be able to significantly bring the quality of the coastal water masses closer to the desired level if drastic lowering of nitrate loadings is achieved. This study reminds the crucial importance of the size and location of the marine target which is supposed to obey the Good Ecological Status constraint: the more extensive the target will be, the more focused on big rivers the optimal scenario will be. This study also shows that different allocations of reduction effort can arise from different optimisation techniques, and pleads for seeing marine threshold as guidelines to be passed through rarely and with a high cost, rather than impassable walls. Moving from a strict optimal solution towards a sub-optimal alternative, which keeps some equity between watersheds, will be probably help stakeholders to carry out the reduction plan.

\section{Acknowledgements}

Half of the budget of this study has been funded by ONEMA, the French National Agency for Water and Aquatic Environments (now included in the French Agency for Biodiversity, AFB). The authors are indebted to their colleagues who helped at Ifremer building the gridded domains of the model (Bénédicte Thouvenin) or gathering data for the numerous rivers (Romain Le Gendre, Jean-Yves Stanisière and Martin Plus). 


\section{Table captions}

Table I. Rivers taken into account, with some descriptors.

Table II. Average annual flow during the 2000-2010 period of the Gironde (Garonne + Dordogne), the Loire and the Seine rivers.

Table III. Reduction rate $(\%)$ of nitrate and phosphate concentrations in the 45 French rivers after Simplex optimisation and after Beale's optimisation when the target is the 0-50m bathymetric strip. 


\section{Figure captions}

Figure 1. Bathymetric grid of the "extended MANGA" model, including the limits of the "restricted MANGA" (black line) and the three coastal zooms (green lines: Eastern Channel, red lines: Brittany, blue lines: Vendée Landes).

Figure 2. Rivers taken into account, with location of the 7 stations used for salinity validation

Figure 3. Location of the Astan station, with the 2000-2011 time-series of the Loire tracer and its cumulative distribution function at this station.

Figure 4. Flow diagram of the biogeochemical model

Figure 5. Taylor's and target diagrams for salinity validation.

Figure 6. Flood regime (left), median regime (middle) and low water regime (right) "receiving basins" of the 6 main French Atlantic-Channel rivers (a basin is limited by a single contour, corresponding to the 100 times dilution). Note that superposing plumes may generate colours different from those of original plumes.

Figure 7. Flood regime (left), median regime (middle) and low water regime (right) "receiving basins" of the 39 secondary French Atlantic-Channel rivers (a basin is limited by a single contour, corresponding to the 100 times dilution). Note that superposing plumes may generate colours different from those of original plumes.

Figure 8. Relationship between the sizes of a watershed and its "receiving basin" (limited by the 100 times dilution contour) for low flow, median and flood regimes.

Figure 9. Response curves of the area (number of grid cells) remaining above the marine quality threshold after minimizing the Beale's FB cost function at various $\lambda$ values, for nitrate or phosphate, in the High Status case applied to the target "All WFD water masses together".

Figure 10. Geographic extension of the different marine target areas under consideration (top: 73 WFD French water masses, middle: 3 MSFD French sub-regions, bottom: 0-50m bathymetric strip).

Figure 11. Top and medium panels: Optimal levels of nitrate (left panel) and phosphate (right panel) reduction in the 45 French rivers as determined by the Simplex method for the High Status (top panel) and Good Status (medium panel). Bottom panel: Optimal levels of nitrate reduction in the 45 French rivers as determined by the Beale's method for the High Status (left panel) and Good Status (right panel). Black bars: mean over the overall 
targets (bathymetric 0-50m strip and WFD masses together); dotted bars: mean over the non-zero abatement local targets (i.e. among the 73 individual WFD water masses).

Figure 12. Marine distribution of nitrate computed by a 3D ecological simulation of January-February 2007 (left panel) or computed from the linear superposition of the mean 45 French river plumes in the present situation (mid panel) and after optimal reduction of the loadings, as determined for the High Status by the Simplex method (right panel). The colour scale applies to concentrations above the $15 \mu \mathrm{mol} / \mathrm{L}$ threshold, the gray one to concentrations below this "High Status" threshold.

Figure 13. Relative decrease $(\%)$ of the $90^{\text {th }}$ percentile of the surface chlorophyll in 2007 when actual nitrate and phosphate river concentrations are replaced by optimal values computed for the Good Status (left column) and High Status (right column) by the Beale (top panel) and Simplex (bottom panel) algorithms respectively.

Figure 14. Relative decrease (\%) of the annual maximum of the surface dinoflagellate biomass in 2007 when actual nitrate and phosphate river concentrations are replaced by optimal values computed for the Good Status (left column) and High Status (right column) by the Beale (top panel) and Simplex (bottom panel) algorithms respectively. 


\section{Supplementary material captions}

Figure 5_S. Comparison of simulated (grey solid line) and measured (black dots) salinity at 7 stations along the French coast during the 2000-2010 period.

Table IV_S. Nitrate concentrations in the 45 French rivers (columns) in the present situation and after Simplex optimisation for various marine targets (rows) in the High Status case. Empty cells mean "No nutrient reduction needed", orange light cells mean an abatement $<33 \%$, orange dark cells an abatement between $33 \%$ and $66 \%$, red cells an abatement $>66 \%$. 


\section{References}

Beliaeff B., Gros P., Belin C., Raffin B., Gailhard I., Durbec J.P., 2001. 'Phytoplankton events' in French coastal waters during 1987-1997., Oceanologica Acta, 2001, 24 (5), 425-433.

Billen G., Garnier J., 2007. River basin nutrient delivery to the coastal sea: assessing its potential to sustain new production of non siliceous algae., Mar. Chem, 106: 148-160.

Blumberg, A.F., Mellor G.L., 1987 A description of a three-dimensional coastal ocean circulation model. In: Three-Dimensional Coastal Ocean Models, Coastal and Estuarine Series, Heaps N. (ed.), American Geophysical Union, 4, 1-16.

Brylinski, J.M., Lagadeuc, V., Gentilhomme, Dupont, J.P., Lafite, R., Dupeuble, P.A., Huault, M.F., Auger, Y., Puskaric, E., Wartel, M., Cabioch, L., 1991. Le fleuve côtier, un phénomène hydrologique en Manche orientale (exemple du Pas de Calais). Oceanologica Acta, n¹1, pp. 197-203.

Daniel A., Soudant D., 2010. Évaluation DCE mai 2010: Élément de qualité: nutriments. Document général pour les masses d'eaux de la France métropolitaine, hors lagunes méditerranéennes - Convention 2009 - Action 4. Onema, Ref. DYNECO/PELAGOS/10.03, 100p.

Desmit X, Thieu V, Billen G, Campuzano F, Dulière V, Garnier J, Lassaletta L, Ménesguen A., Neves R, Pinto L., Silvestre M, Sobrinho JL, Lacroix G., 2018. Reducing marine eutrophication may require a paradigmatic change. Science of the total environment, 635, 1444-1466.

Ferrer, L., Fontán, A., Mader, J., Chust, G., González, M., Valencia, V., Uriarte, Ad., Collins, M.B., 2009. Lowsalinity plumes in the oceanic region of the Basque Country. Continental Shelf Research, 29(8), 970-984.

Gren, I.-M., 2009. A numerical model for dynamic cost effective mitigation of eutrophication with spatial heterogeneity in the Baltic Sea-technical report. Swedish University of Agricultural Sciences (SLU) Working Paper Series, 3, Uppsala., 32 p.

Kelly-Gerreyn, B. A., Hydes, D. J., Jegou, A. M., Lazure, P., Fernand, L. J., Puillat, I., Garcia-Soto, C. Low, 2006. Low salinity intrusions in the western English Channel, Cont. Shelf Res., 26, 1241-1257.

Lacroix, G., Ruddick, K.G., Ozer, J., Lancelot, C., 2004. Modelling the impact of the Scheldt and Rhine/Meuse plumes on the salinity distribution in Belgian waters (southern North Sea). Journal of Sea Research 52 (3), 149163 
Lazure P., Dumas F., 2008. An external-internal mode coupling for a 3D hydrodynamical model for applications at regional scale (MARS). Advances in Water Resources, 31(2), 233-250.

Linker L.C., Batiuk R.A., Shenk G.W., Cerco C.F., 2013. Development of the Chesapeake Bay Watershed Total Maximum Daily Load Allocation. Journal of the American Water Resources Association (JAWRA), 49(5): 9861006.

Los F.J., Troost T.A., Van Beek J.K.L., 2014. Finding the optimal reduction to meet all targets-Applying Linear Programming with a nutrient tracer model of the North Sea. Journal of Marine Systems, 131, 91-101.

Loyer S., Lampert L., Ménesguen A., Cann P., Labasque T., 2006. Seasonal evolution of the nutrient pattern on Biscay Bay continental shelf over the years 1999-2000. Scientia marina, 70(1), 31-46.

Lyard F., Lefevre F., Letellier T., Francis O., 2006. Modelling the global ocean tides: modern insights from FES2004. Ocean Dynamics, 56, 394-415.

Ménesguen A., Dussauze M., Dumas F., Thouvenin B., Garnier V., Lecornu F., Repécaud M., in revision. Ecological model of the Bay of Biscay and English Channel shelf for ecological status assessment. Part 1: Nutrients, phytoplankton and oxygen. Ocean Modelling.

Ménesguen A., Piriou J.-Y., 1995. Nitrogen loadings and macroalgal (Ulva sp.) mass accumulation in Brittany (France). Ophelia, 42, 227-237.

Meybeck M., 1989. The quality of rivers : from pristine stage to global pollution. Palaeogeogr. Palaeocl., 75, 283-309.

National Research Council (NRC), 2009. Nutrient Control Actions for Improving Water Quality in the Mississippi River Basin and Northern Gulf of Mexico. Committee on the Mississippi River and the Clean Water Act Water Science and Technology Board Division on Earth and Life Studies. The National Academies Press, Washington, DC. 79 pp.

Nezlin, N.P., DiGiacomo, P.M., Stein, E.D., Ackerman, D., 2005. Stormwater runoff plumes observed by SeaWiFS radiometer in the Southern California Bight. Remote Sensing of Environment 98, 494-510.

OSPAR 2013. "Distance to Target" Modelling Assessment. Ed: Lenhart, H., Desmit, X., Grosse, F., Mills, D., Lacroix, G., Los, H.J., Ménesguen A., Pätsch, J., Troost, T., van der Molen, J., van Leeuwen, S. and Wakelin, S. OSPAR commission, Eutrophication series n599, 80 pages. 
Perrot T., Rossi N., Ménesguen A., Dumas F., 2014. Modelling green macroalgal blooms on the coasts of Brittany, France to enhance water quality management. J. Mar. Sys., 132, 38-53.

Rabotyagov, S., Jha M., Cambell T., 2010. Searching for efficiency: Least cost nonpoint source pollution control with multiple pollutants, practices and targets. Journal of Natural and Environmental Sciences, 1(2):75-90.

Smith, E.L., 1936. Photosynthesis in relation to light and carbon dioxide. Proceedings of the National Academy of Sciences, 22: 504-511.

Warrick, J., Fong D., 2004. Dispersal scaling from the world's rivers, Geophys. Res. Lett., 31, L04301, doi:10.1029/2003GL019114. 


\begin{tabular}{|c|c|c|c|c|c|c|}
\hline River name & $\begin{array}{l}\text { Watershed } \\
\text { area }(\mathrm{km} 2)\end{array}$ & $\begin{array}{l}2000-2010 \text { mean } \\
\text { flow rate }(\mathrm{m} 3 / \mathrm{s})\end{array}$ & $\begin{array}{l}2000-2010 \text { mean } \\
{\left[\mathrm{NO}_{3}\right](\mu \mathrm{mol} / \mathrm{L})}\end{array}$ & $\begin{array}{l}\text { 2000-2010 mean } \\
{\left[\mathrm{PO}_{4}\right](\mu \mathrm{mol} / \mathrm{L})}\end{array}$ & River name & $\begin{array}{l}\text { Watershed } \\
\text { area }(\mathbf{k m} 2)\end{array}$ \\
\hline \multicolumn{3}{|c|}{ France } & & & Haute-Perche & 149 \\
\hline $\mathrm{Aa}$ & 1215 & 15.7 & 375 & 5.1 & Falleron & 423 \\
\hline Canche & 1274 & 18.5 & 372 & 2.1 & Sallertaine & 384 \\
\hline Authie & 1304 & 13.9 & 350 & 1.5 & Vie & 495 \\
\hline Somme & 6550 & 46.5 & 326 & 1.7 & Lay & 1750 \\
\hline Bresle & 748 & 7.2 & 261 & 1.3 & Sèvre niortaise & 3650 \\
\hline Arques & 1050 & 10.2 & 274 & 2.8 & Charente & 9855 \\
\hline Seine & 78650 & 519 & 411 & 9.1 & Seudre & 855 \\
\hline Touques & 1305 & 10.2 & 196 & 3.2 & Dordogne & 23870 \\
\hline Dives & 1573 & 8 & 504 & 3.1 & Garonne & 55000 \\
\hline Orne & 2932 & 35 & 403 & 2.0 & Leyre & 1700 \\
\hline Seulles & 420 & 2.3 & 476 & 4.0 & Adour & 16880 \\
\hline Vire+Aure & 1969 & 26.5 & 265 & 7.0 & \multicolumn{2}{|c|}{ Netherlands/Be } \\
\hline Douve & 1070 & 12.3 & 190 & 2.2 & Rhine & 160221 \\
\hline Sée & 477 & 10 & 466 & 1.1 & Scheldt & 18949 \\
\hline Sélune & 1038 & 12.8 & 524 & 1.0 & Maas & 32047 \\
\hline Sienne & 580 & 9.4 & 281 & 2.6 & \multicolumn{2}{|r|}{ United Kingd } \\
\hline Couesnon & 1124 & 10.3 & 606 & 1.6 & Thames & 13514 \\
\hline Rance & 1195 & 7 & 482 & 1.9 & Stour & 2994 \\
\hline Gouessant+Urne+Gouet & 806 & $2.8+3.7+0.4$ & 630 & 2.2 & Itchen & 471 \\
\hline Arguenon & 590 & 5 & 649 & 1.7 & Test & 1206 \\
\hline Trieux & 495 & 6.2 & 634 & 1.3 & Exe & 1252 \\
\hline Jaudy & 520 & 5.7 & 577 & 2.3 & Taw & 987 \\
\hline Léguer & 480 & 8.5 & 433 & 1.7 & Torridge & 799 \\
\hline Roscoat+Yar+Douron & 202 & $0.4+0.8+0.4$ & 480 & 1.2 & Avon & 2229 \\
\hline Dourduf+Jarlot & $78+233$ & $1+4$ & 550 & 1.6 & Tywi & 1326 \\
\hline Penzé & 210 & 5 & 799 & 4.6 & Severn & 11381 \\
\hline Elorn & 260 & 6.4 & 537 & 1.4 & \multicolumn{2}{|r|}{ Spain } \\
\hline Aulne & 1875 & 34.5 & 351 & 1.0 & Deba & 522 \\
\hline Odet & 724 & 16.7 & 442 & 0.8 & Urola & 342 \\
\hline Laïta & 917 & 16.9 & 373 & 1.4 & Oria & 863 \\
\hline Blavet+Scorff & 2464 & $29.4+8.5$ & 440 & 1.0 & Urumea & 272 \\
\hline Vilaine & 10500 & 78.5 & 390 & 1.2 & Oiartzun & 85 \\
\hline Loire & 117000 & 880 & 212 & 1.4 & & \\
\hline
\end{tabular}

Table I. 


\begin{tabular}{|c|c|c|c|c|c|c|c|c|c|c|c|c|}
\hline & $\begin{array}{c}200 \\
0\end{array}$ & 2001 & 2002 & 2003 & 2004 & 2005 & 2006 & 2007 & 2008 & 2009 & 2010 & $\begin{array}{c}2000 / 2 \\
010\end{array}$ \\
\hline $\begin{array}{l}\text { GIRO } \\
\text { NDE }\end{array}$ & 999 & 979 & 695 & 808 & 913 & 544 & 689 & 739 & 932 & 799 & 722 & 803 \\
\hline $\begin{array}{c}\text { LOIR } \\
\text { E }\end{array}$ & $\begin{array}{c}116 \\
9\end{array}$ & 1312 & 753 & 910 & 879 & 565 & 724 & 909 & 1006 & 618 & 820 & 881 \\
\hline $\begin{array}{c}\text { SEIN } \\
\text { E }\end{array}$ & 737 & 914 & 637 & 439 & 418 & 343 & 461 & 503 & 521 & 329 & 408 & 519 \\
\hline
\end{tabular}

5

6

7

8

Table II

9

10 


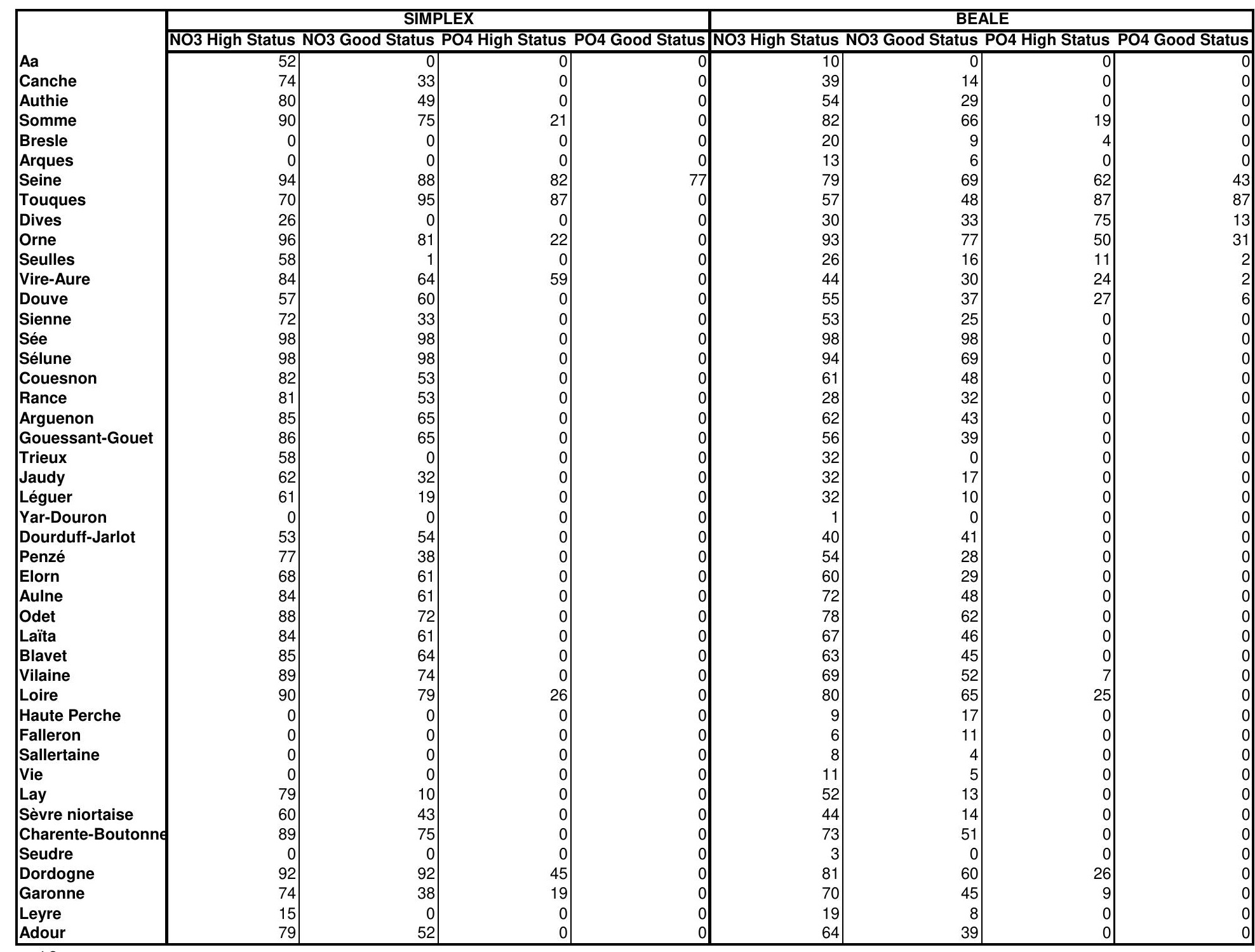

12

Table III. 


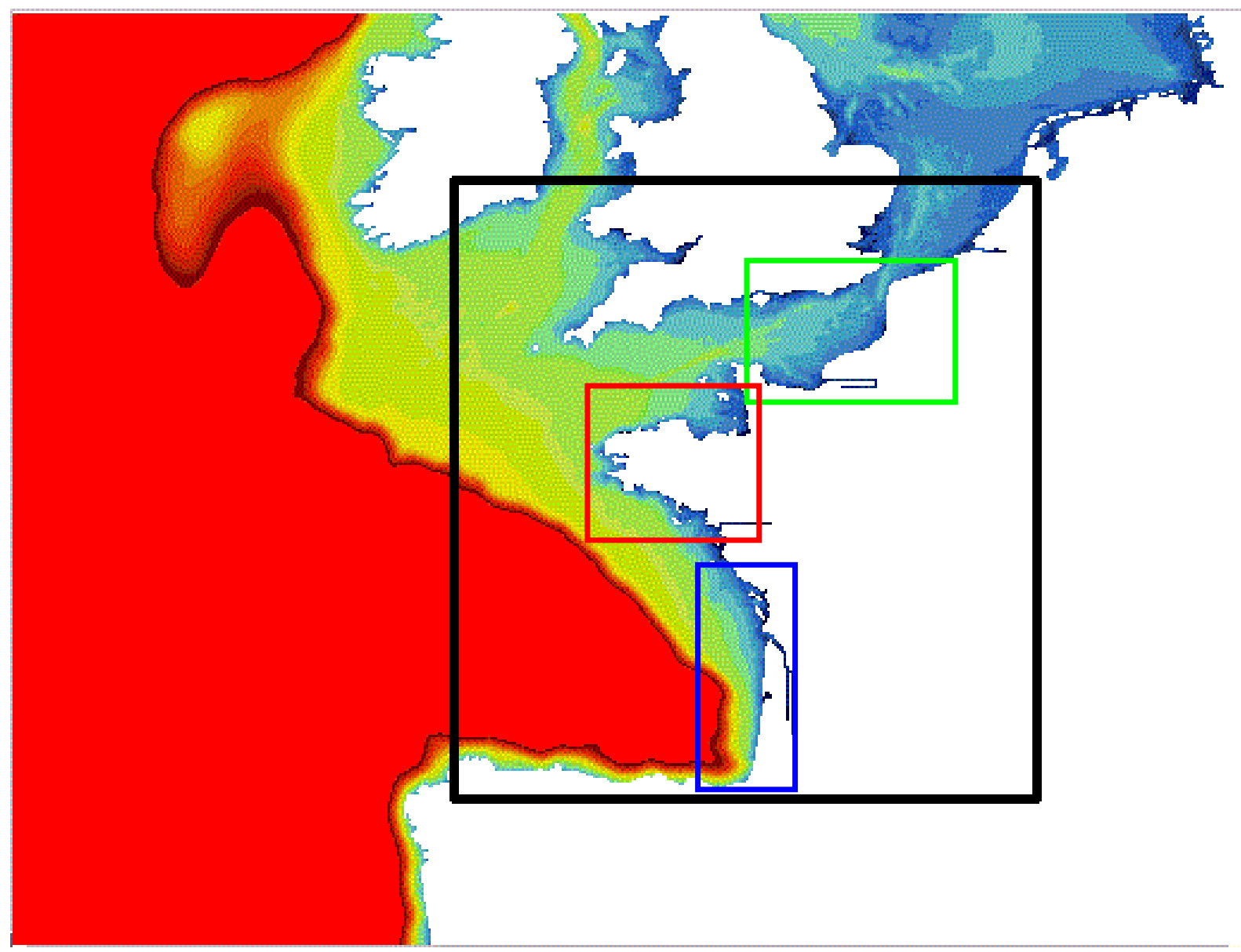

20

21
Figure 1 


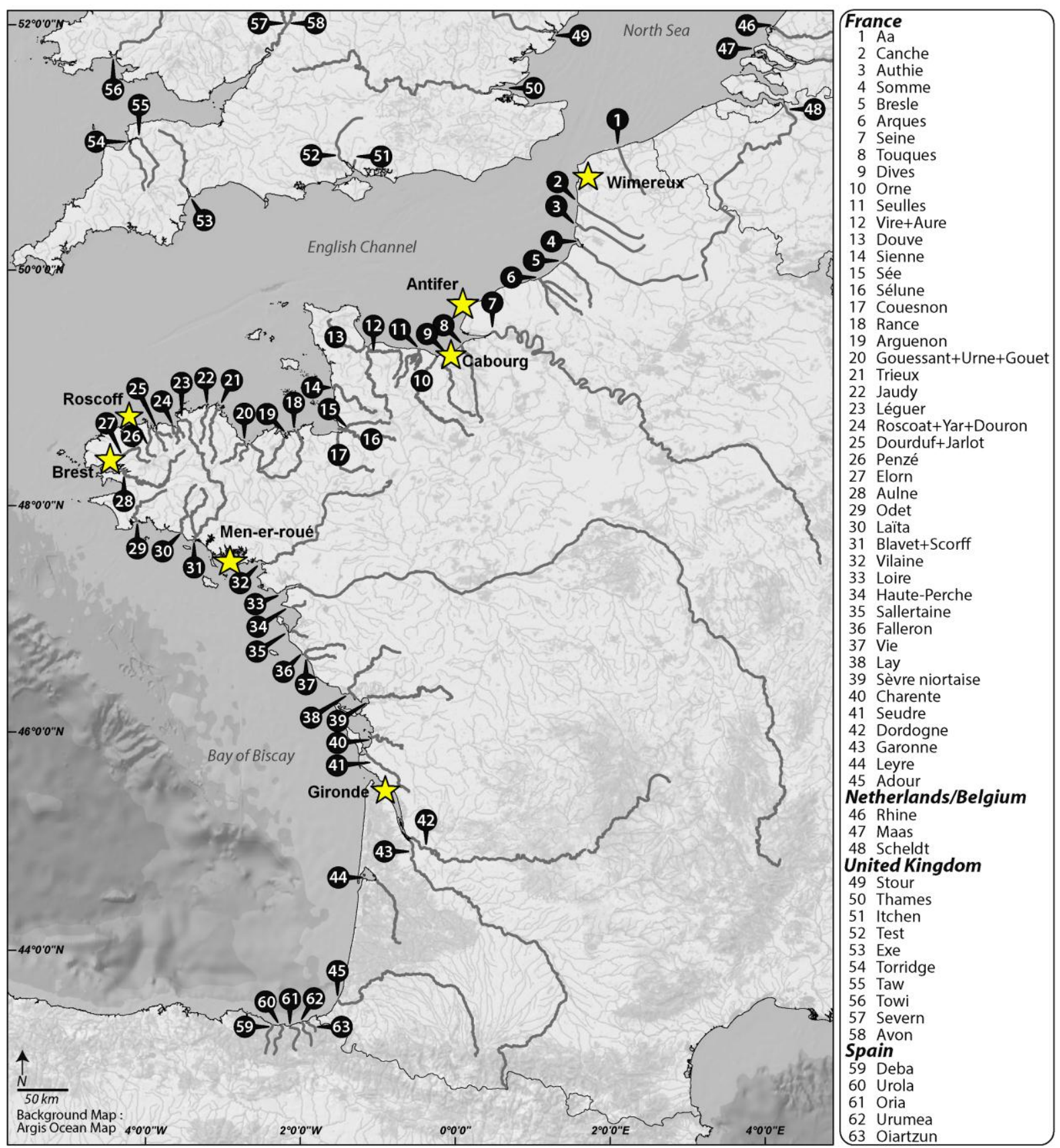

Figure 2 

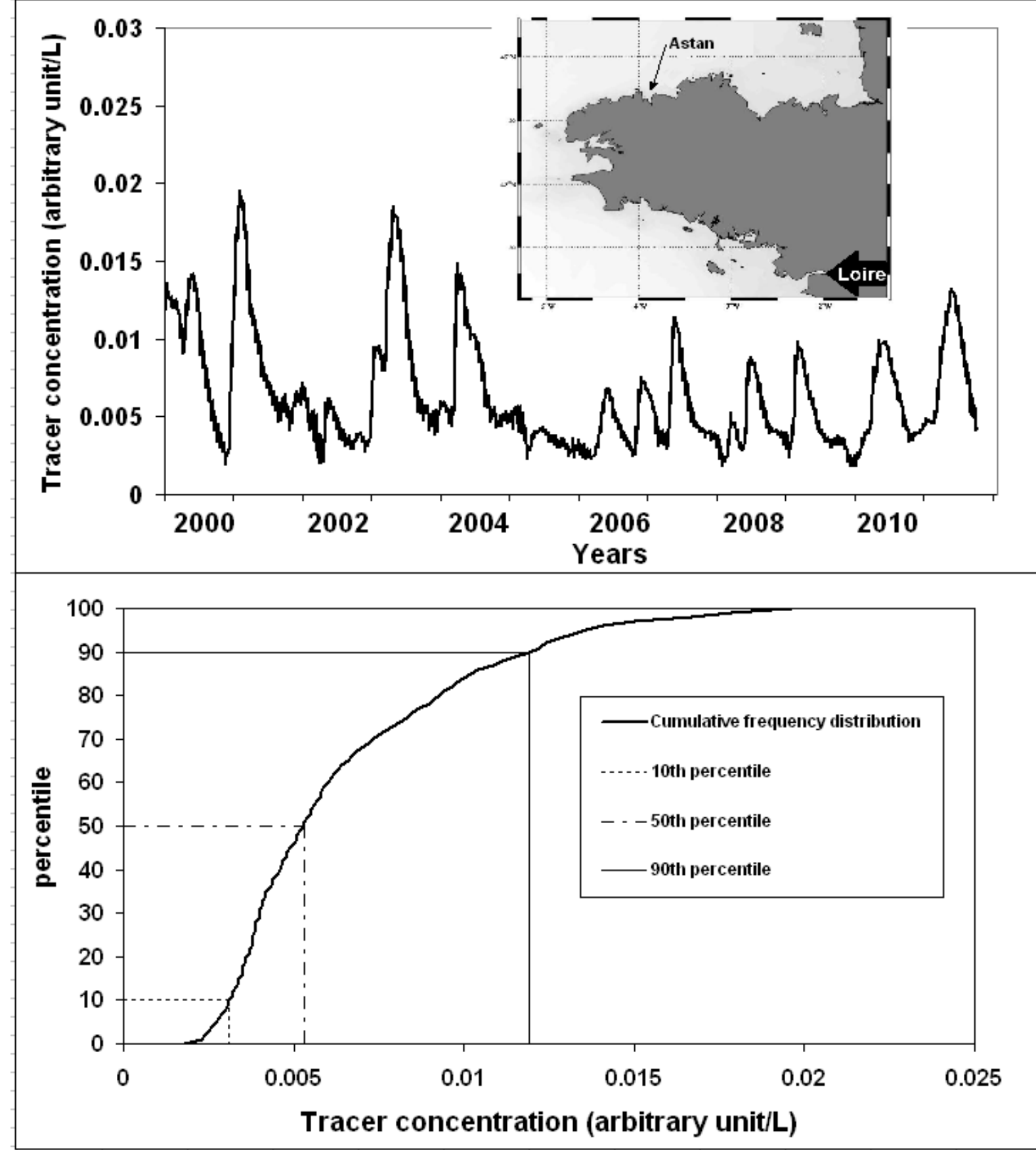


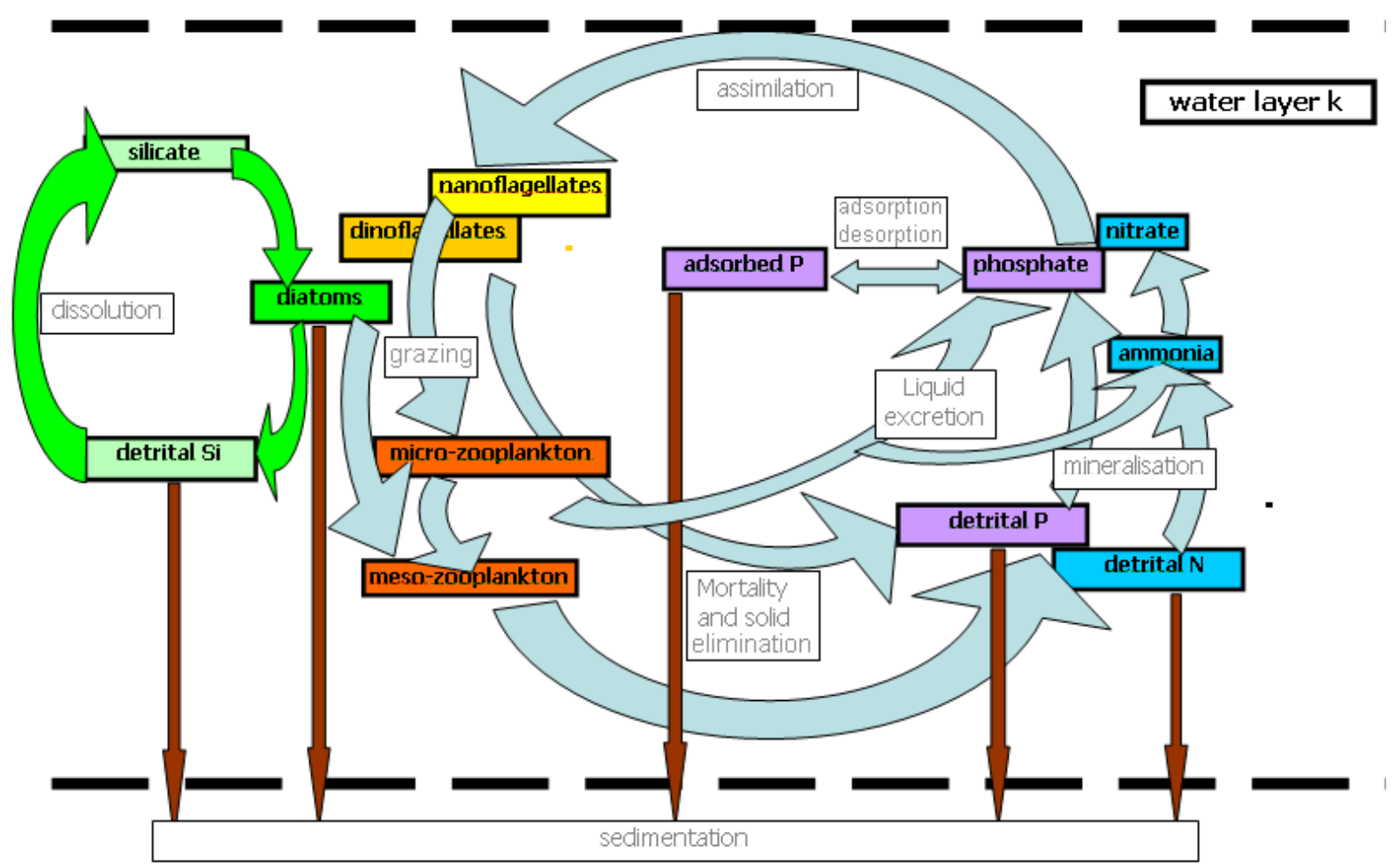




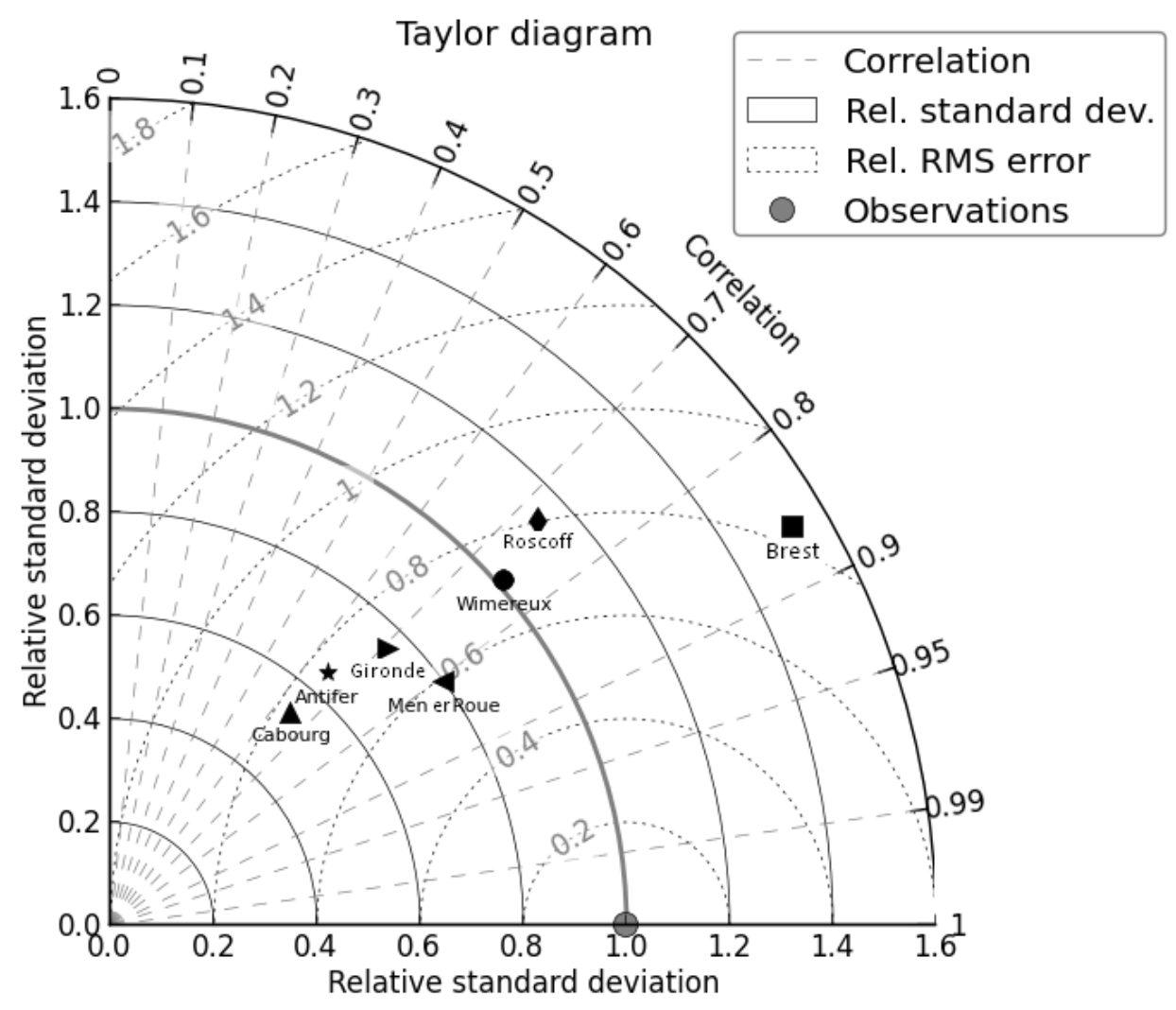

41

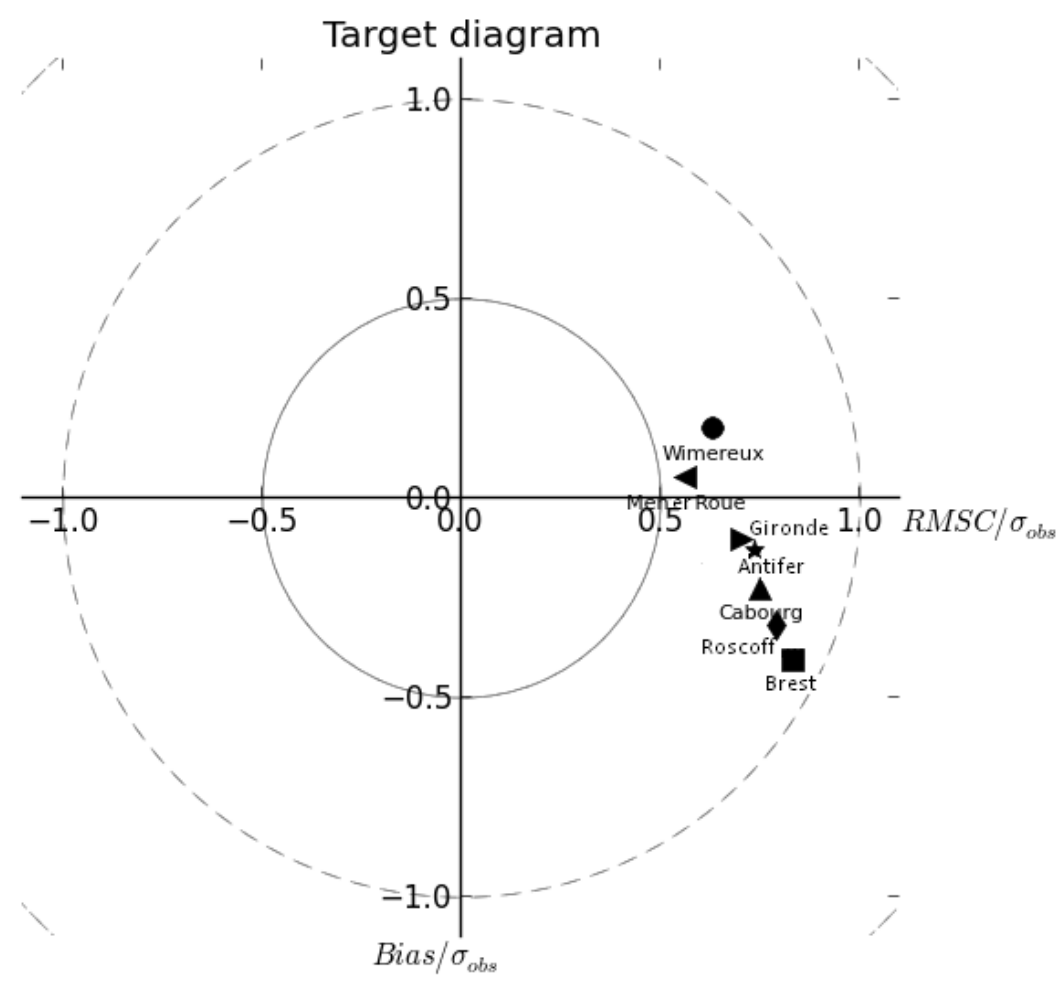



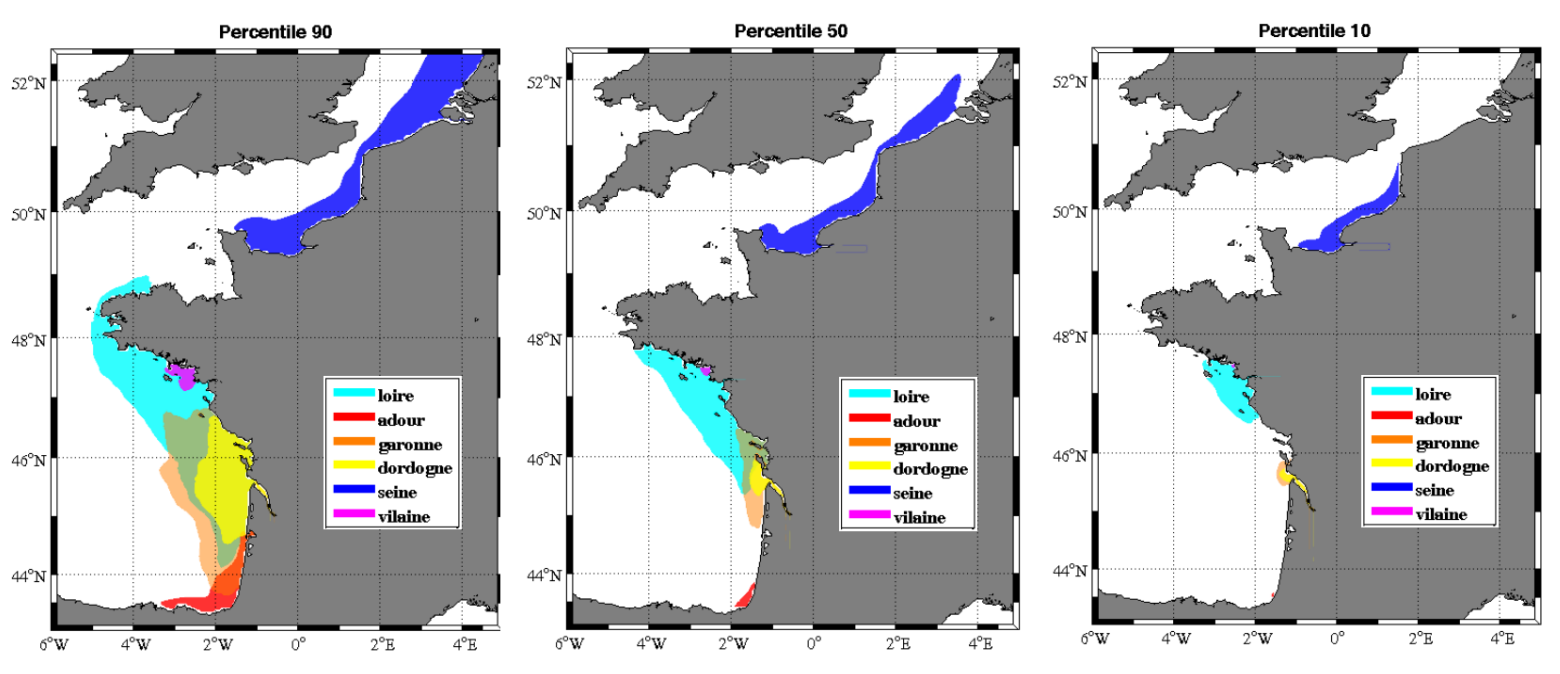

Figure 6 

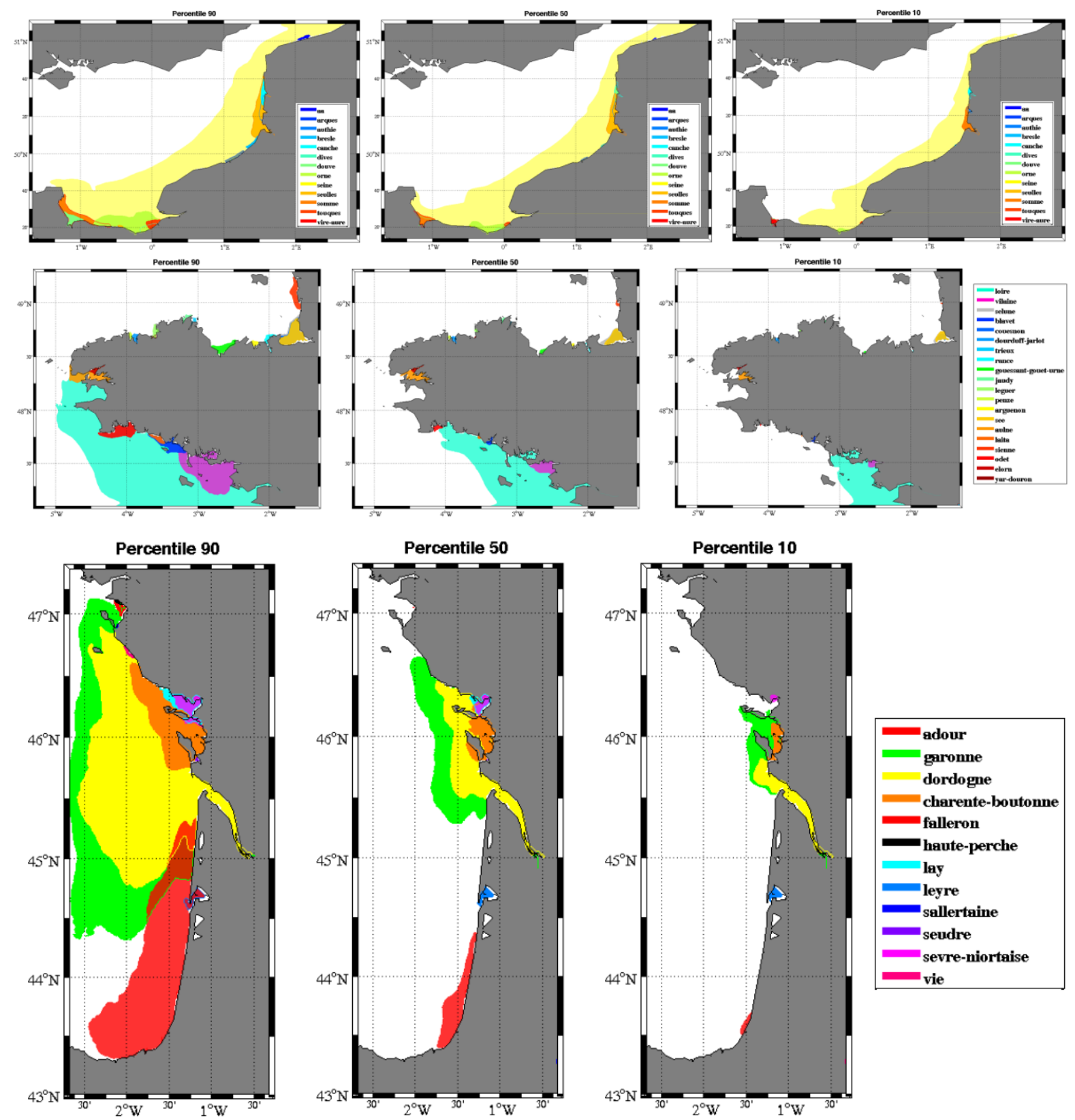


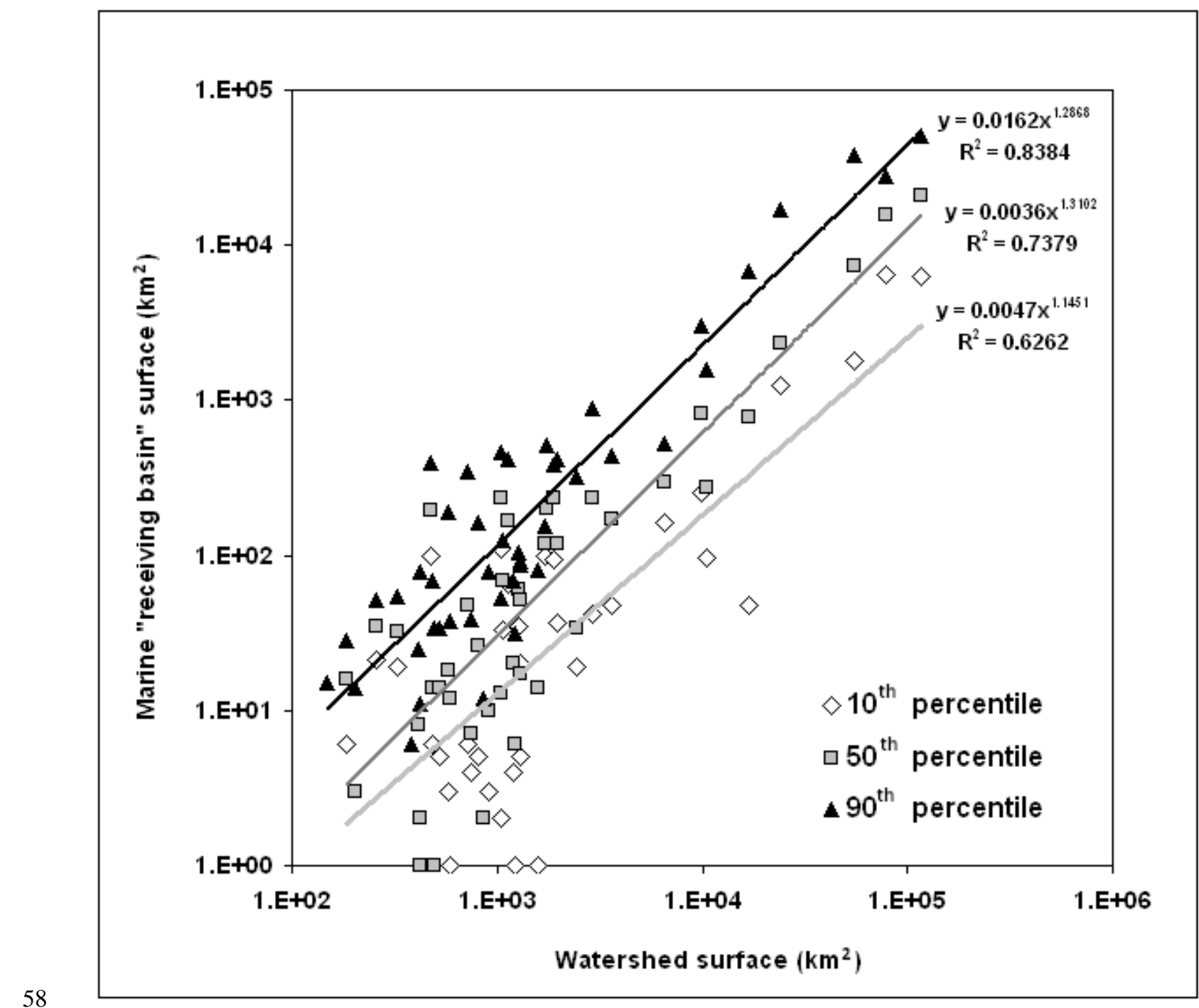




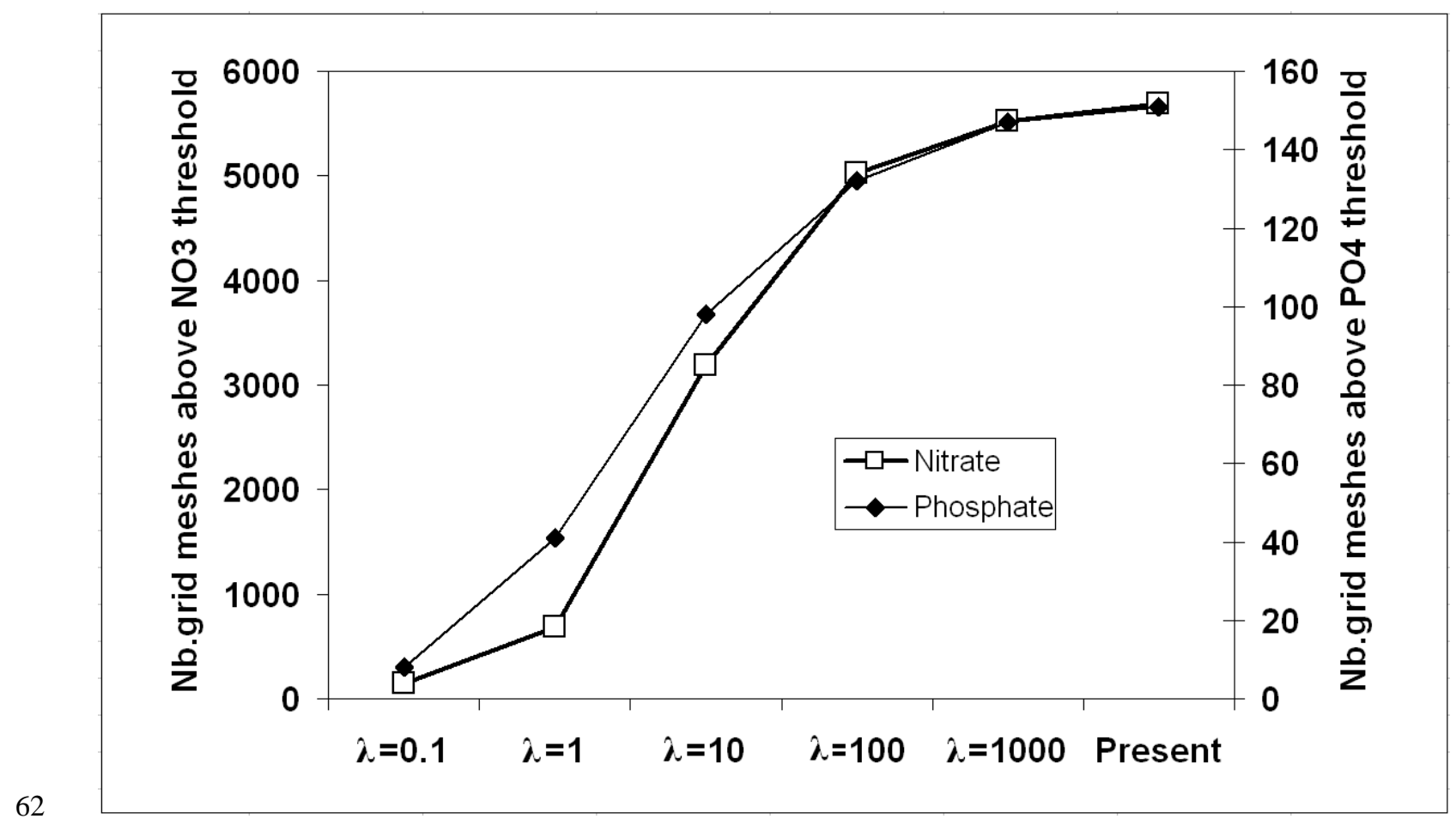



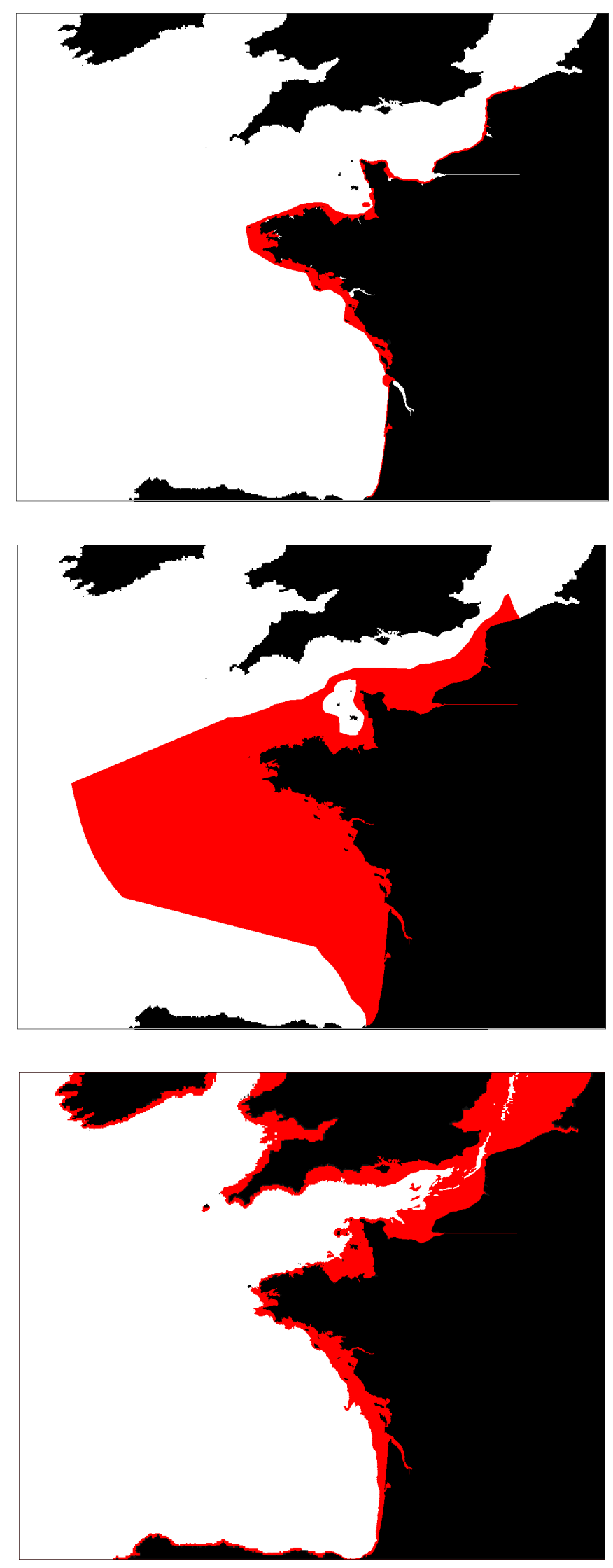

Figure 10 

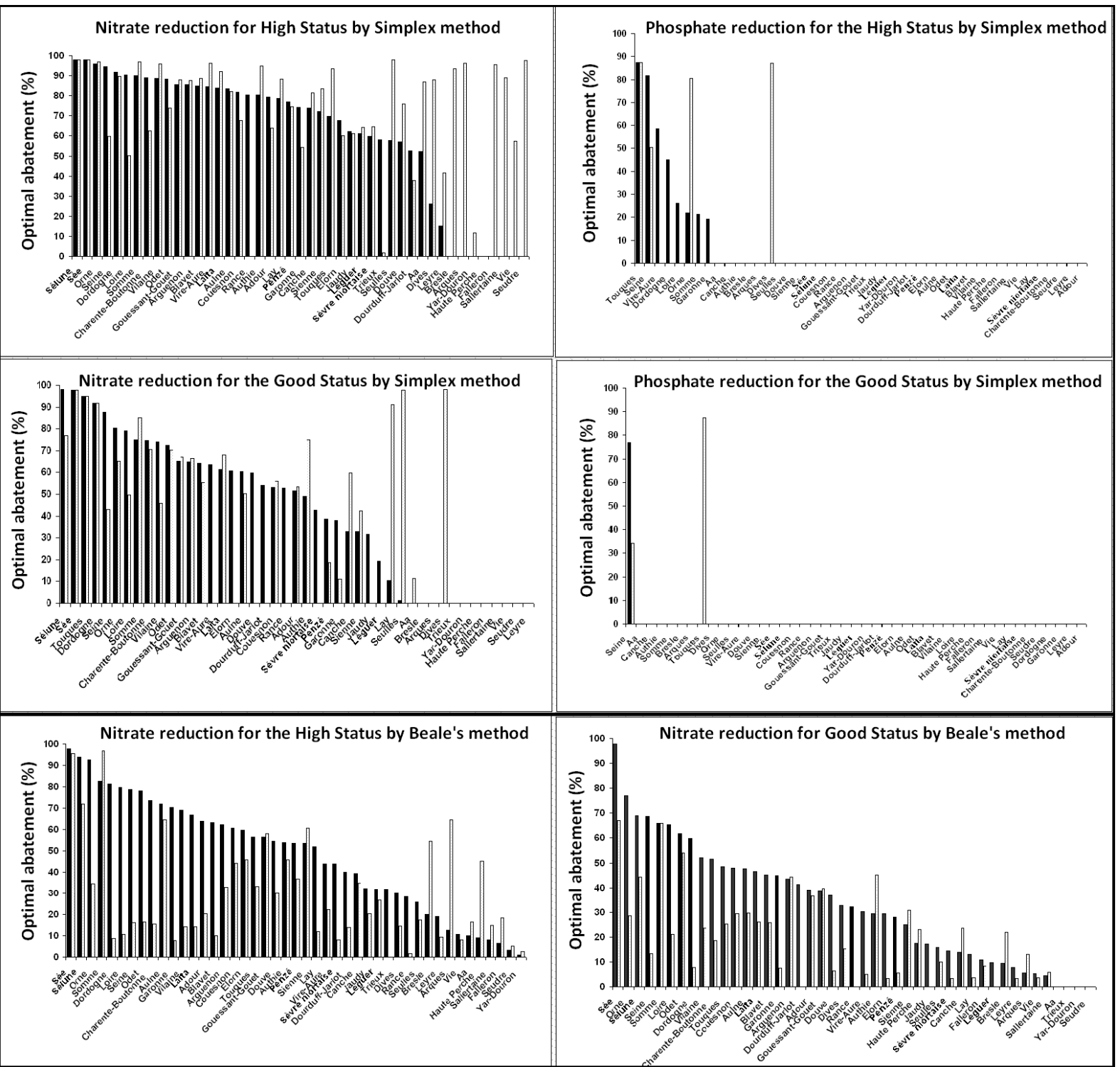


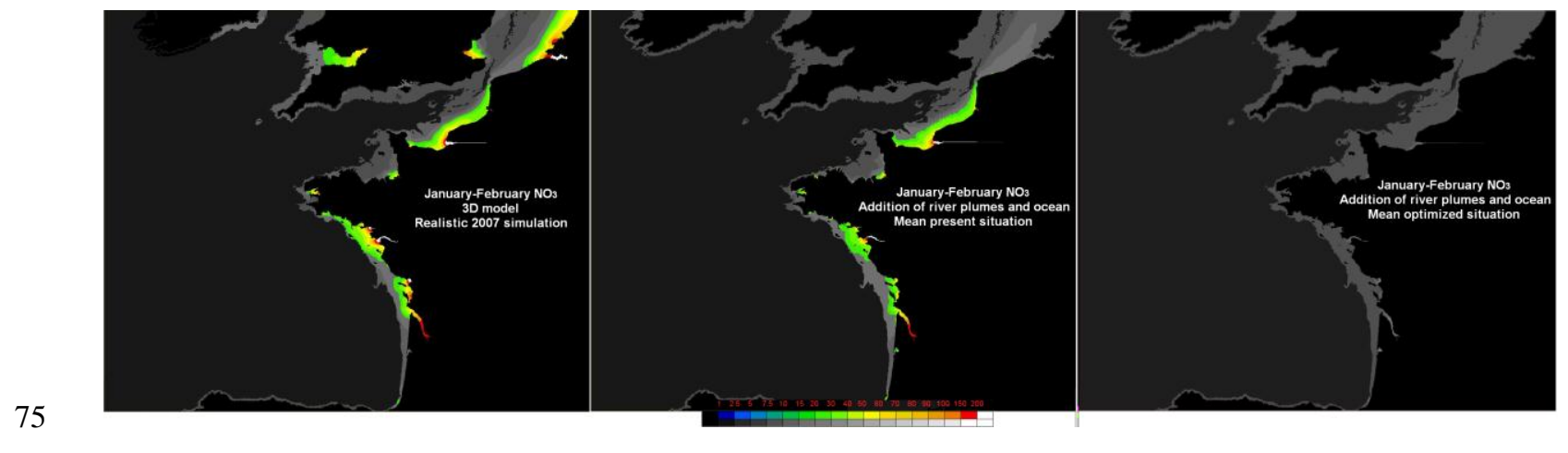

Figure 12

77

78 

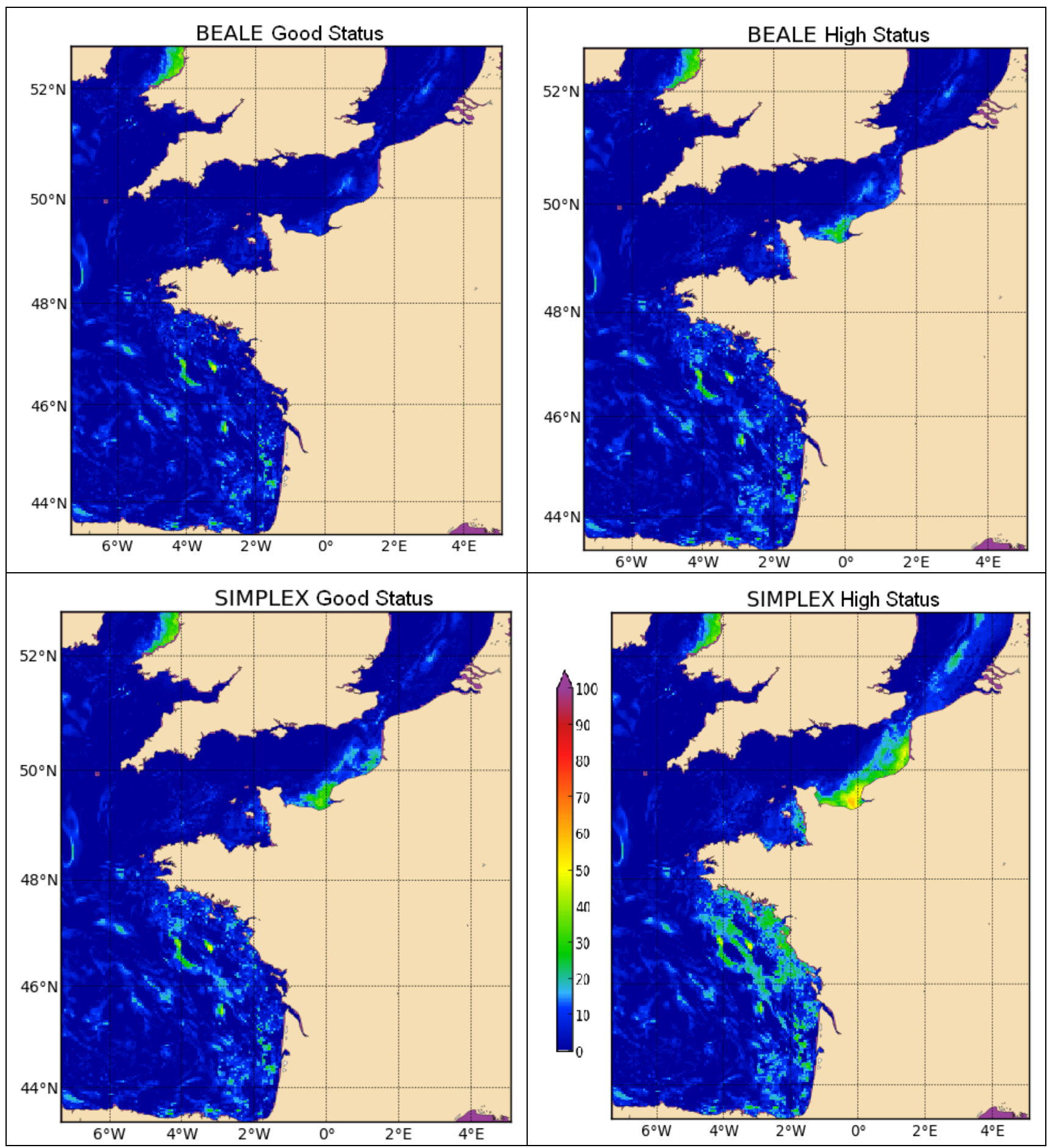

80 


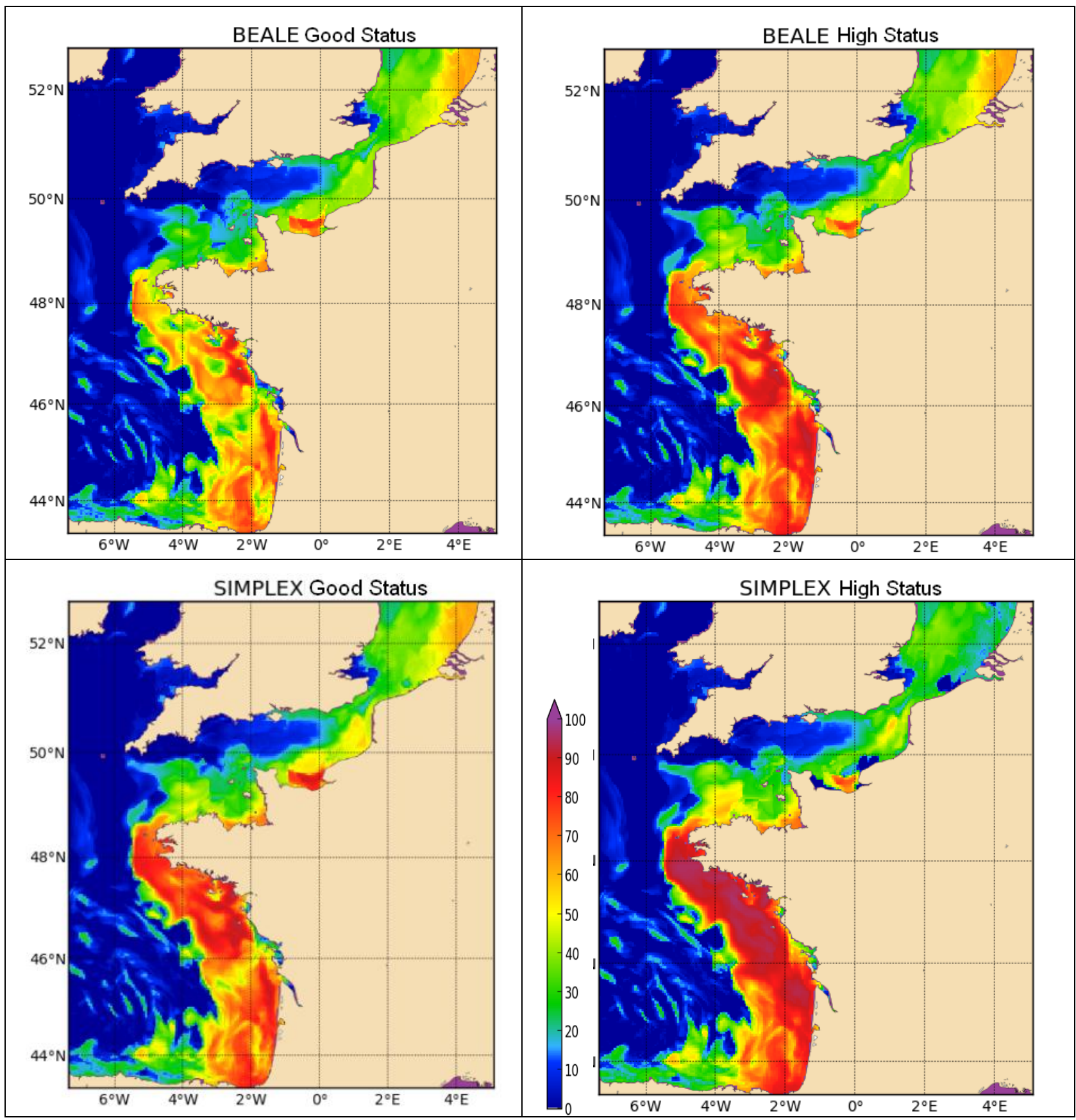



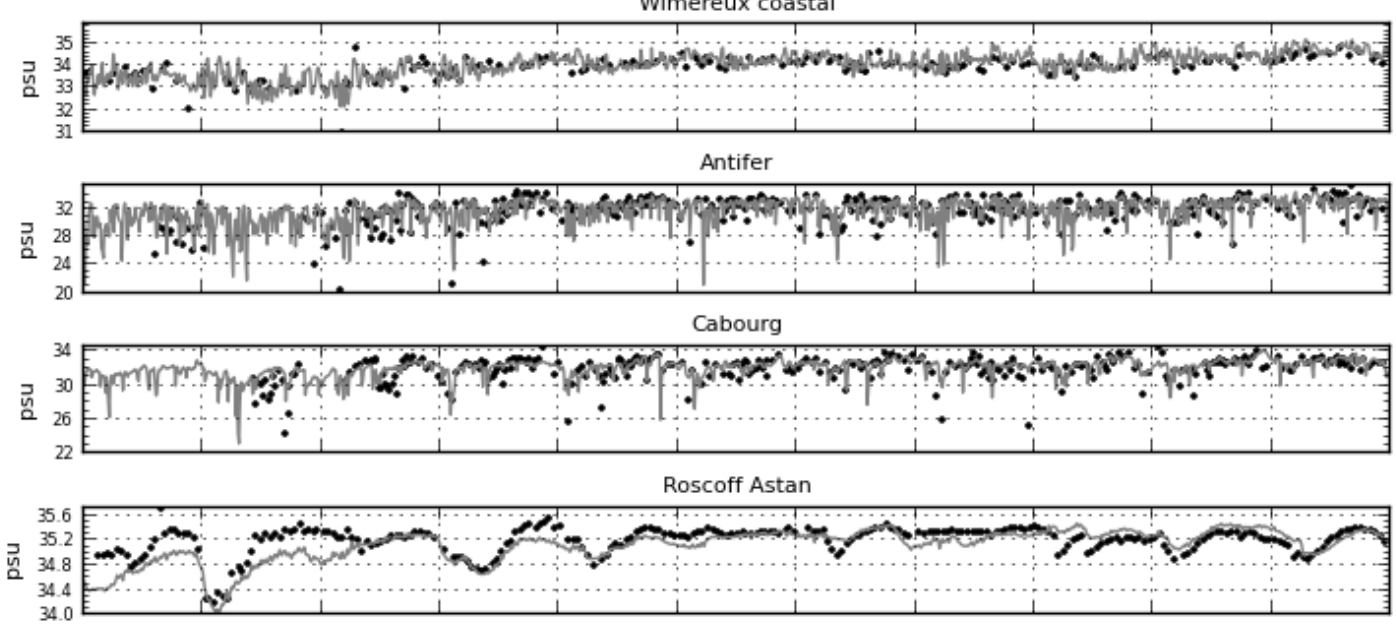

Brest Portzic

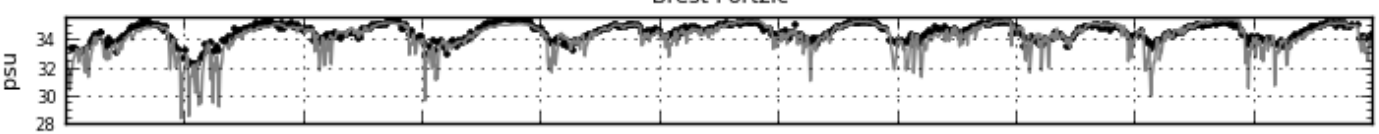

Meneroue

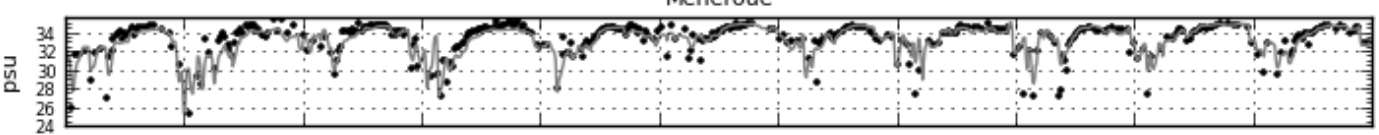

Gironde pk86

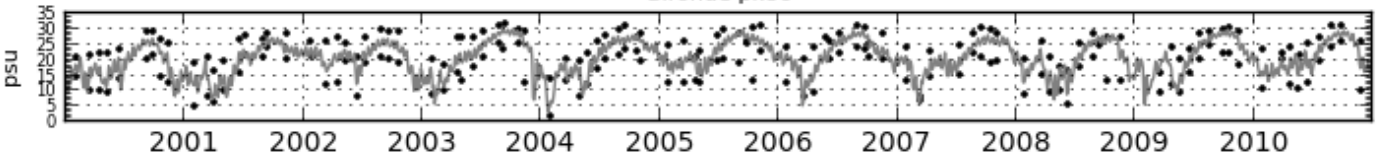




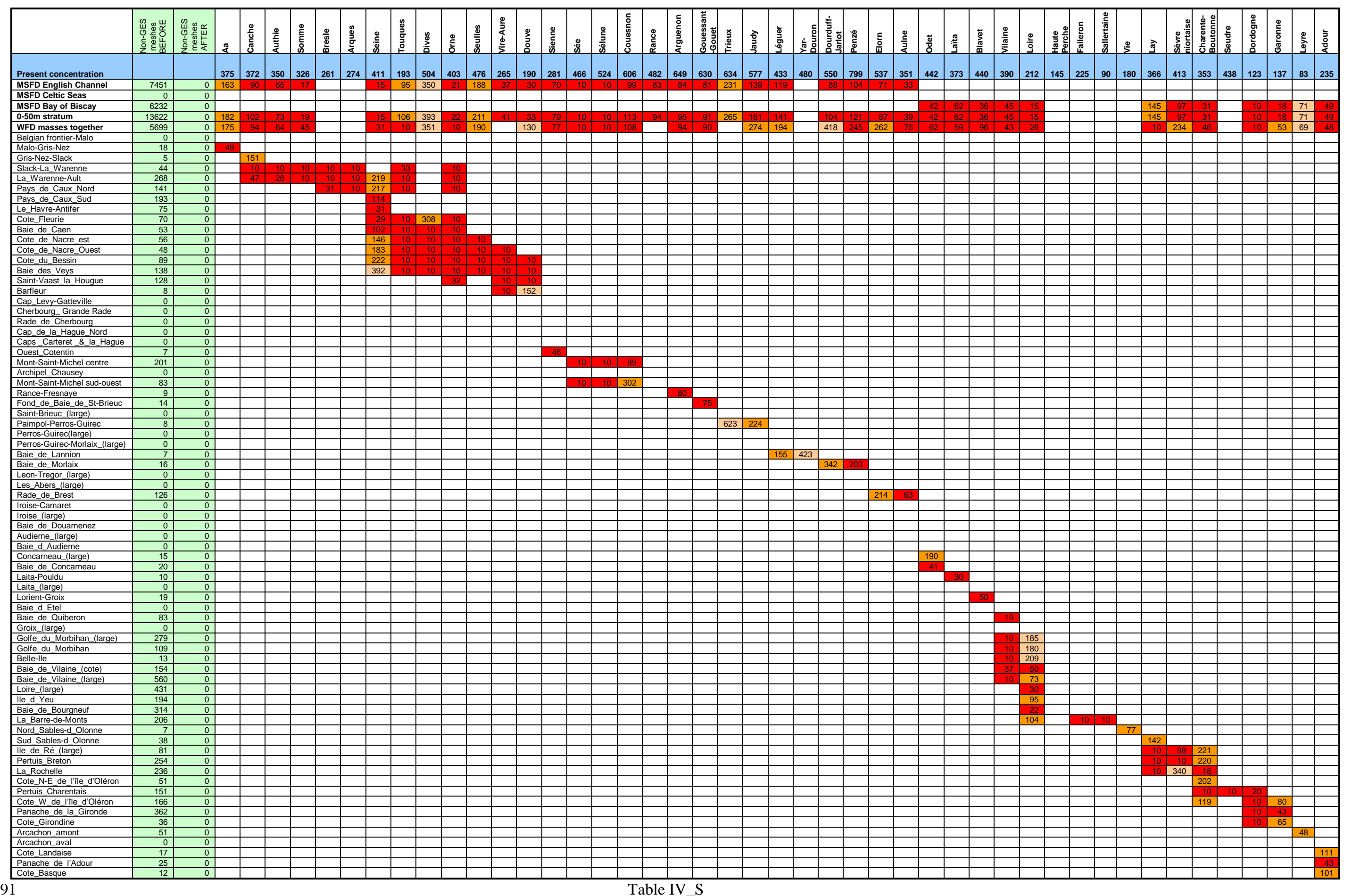


